\title{
Perspectives for Greening European Fossil-Fuel Infrastructures Through Use of Biomass: The Case of Liquid Biofuels Based on Lignocellulosic Resources
}

\author{
Paraskevi Karka, Filip Johnsson and Stavros Papadokonstantakis* \\ Department of Space, Earth and Environment, Division of Energy Technology, Chalmers University of Technology, \\ Gothenburg, Sweden
}

\section{OPEN ACCESS}

Edited by:

Luis Puigjaner,

Universitat Politecnica de

Catalunya, Spain

Reviewed by:

Elisabeth Wetterlund,

Luleå University of

Technology, Sweden

Pinaki Dey,

Karunya Institute of Technology and

Sciences, India

Jay Prakash Verma,

Banaras Hindu University, India

*Correspondence:

Stavros Papadokonstantakis

stavros.papadokonstantakis@

chamers.se

Specialty section:

This article was submitted to

Process and Energy Systems

Engineering,

a section of the journal

Frontiers in Energy Research

Received: 02 December 2020 Accepted: 08 March 2021

Published: 06 April 2021

Citation:

Karka P, Johnsson F and

Papadokonstantakis S (2021)

Perspectives for Greening European

Fossil-Fuel Infrastructures Through

Use of Biomass: The Case of Liquid Biofuels Based on Lignocellulosic

Resources.

Front. Energy Res. 9:636782. doi: 10.3389/fenrg.2021.636782
Given the importance of climate change it is vital to find a transition away from fossil fuels. The transition will include electrification of several sectors, for example road transport, but considering the strong dependency on carbon-based fuels and associated infrastructures, it is reasonable to assume that biomass-based hydrocarbon will play a key role to smoothen the transition away from fossil fuels. This study provides an analysis of direct and indirect technological options for liquid biofuels based on lignocellulosic resources in the context of greening European fossil-fuel infrastructures. Direct options are those which result in integration of biogenic feedstock in a fossil-based process and then co-processing in a downstream conventional unit or substituting a conventional part of the production chain of a liquid fuel by a bio-based one. Indirect options are those which pave the way for ramping-up biomass supply chain in the form of infrastructure and market. Examples of direct options in the focus of this study are biomass gasification for production of intermediates and biomass pyrolysis substituting fossil feedstock. Examples of indirect options are co-firing biomass in coal-fired power plants and integrating biomass gasification plants with district heating $(\mathrm{DH})$ networks. Such options are important for establishing biomass supply chains and markets. This study also assesses the potential of biomass use in other industrial sectors not directly related with fossil-based fuel or energy production, such as the pulp and paper industry and the iron and steel industry. In this context, opportunities and barriers for both direct and indirect greening options are discussed, focusing mainly on technological and logistic aspects. It is highlighted that fossil-fuel infrastructures can act as drivers for the development of advanced biofuels production as they can reduce the initial risks, in terms of cost and technological maturity, offering the opportunity to increase gradually the demand for biomass, and develop the logistic infrastructure. It is, however, important to make sure that such biofuel production processes are part of a long-term strategy, which needs incentives to overcome current barriers and eventually phase out fossil infrastructures.

Keywords: integration, bioeconomy, gasification, pyrolysis, district heating, lignocellulosic biomass, advanced fuels, co-firing 


\section{INTRODUCTION}

The European Union (EU) aims at the transition toward a climate neutral economy in order to reach the goals of the Paris Agreement (United Nations Climate Change, 2016) adopting various action plans and strategies. In short term the "2030 climate and energy framework" (European Commission, 2030 climate \& energy framework, Climate Action $^{1}$ ) includes EUwide targets and policy objectives targeting at the reduction of greenhouse gas (GHG) emissions, increased share of renewable energy and improvement in energy efficiency. In long term, EU targets at climate neutrality by 2050 (European Commission, 2050 long-term strategy, Climate Action ${ }^{2}$ ) in the framework of the European Green Deal (European Commission, A European Green $\mathrm{Deal}^{3}$ ), which includes action plans toward a resource efficient, circular economy, restoration of biodiversity, and pollution reduction. In this context, it is likely that in the foreseeable future the fossil-fuel infrastructure will involve significant downsizing. A combination of measures will be most likely needed to compensate this reduced dependency on fossil fuels, such as change of end-user consumption patterns, evolution of engines, more efficient logistics, promotion of direct and indirect electrification, and use of liquid biofuels, either as drop-in or in blending. Whereas, passenger and light duty road transportation could be benefitted from electrification aviation, shipping, and long-haul road transportation are expected to-at least to a large share-rely on over the next decades (Gudde et al., 2019).

With respect to increasing the share of liquid (advanced) biofuels, a major challenge is their production cost in relation to the fossil fuel alternatives. This is of fundamental importance, since drastic reductions in production costs of biofuels cannot be expected, while the cost of the biomass feedstock remains a substantial part of the fuel price (Thunman et al., 2018; IEA Bioenergy Report, 2020). Both governmental support for supporting investments to scale-up the production of biofuels and long-term market conditions in favor of biofuels are required. The current regulations in energy use and climate change have not so far created an environment of longterm stability to reduce capital risk and unlock massive largescale investments on renewable sources (Fuels Europe, 2018). Two representative policies have a significant impact on the future of transportation fuels: Fuel Quality Directive (European Commission, Fuel Quality ${ }^{4}$ ) with $6 \%$ emissions reductions

\footnotetext{
Abbreviations: bio-SNG, bio-synthetic natural gas; BFB, bubbling fluidized bed; BTL, biomass-to-liquids; CCS, carbon capture and storage; CFB, circulating fluidized bed; CTL, coal-to-liquids; DFB, dual fluidized bed; DME, dimethyl ether; DH, district heating; EU, European Union; FCC, fluid catalytic cracking; FT, Fischer-Tropsch; GHG, greenhouse gas; HDO, hydrodeoxygenation; HEFA, hydrotreated ester and fatty acids; LBG, liquified biogas; LPG, liquefied petroleum gas; TMP, thermo-mechanical pulp; TRL, technology readiness level; VGO, vacuum gas oil.

${ }^{1}$ https://ec.europa.eu/clima/policies/strategies/2030_en

${ }^{2}$ https://ec.europa.eu/clima/policies/strategies/2050_en

${ }^{3}$ https://ec.europa.eu/info/strategy/priorities-2019-2024/european-greendeal_en

${ }^{4}$ European Commission, Fuel Quality. https://ec.europa.eu/clima/policies/ transport/fuel_en
}

target by 2020 using biofuels, electricity, e-fuels, and upstream emissions reduction and the Renewable Energy DirectiveRecast to 2030 (European Commission, Renewable EnergyRecast to 2030 (RED II), EU Science Hub $^{5}$ ) including targets for road and rail transport sub-sectors by 2030 and requiring a minimum of $14 \%$ of the energy consumed as renewable energy. The Emissions Trading System [European Commission, EU Emissions Trading System (EU ETS), Climate Action ${ }^{6}$ ] is also expanded for the aviation sector (Fuels Europe, 2018).

Eventually, such policies should be effective at the development of efficient biomass supply logistics, which is a vital factor for the success of liquid biofuels. There is significant potential for establishing biomass supply systems for different types of lignocellulosic feedstock such as from forests and short rotation crops. For instance, EU countries like Sweden and Finland have well-developed forest industry including production of some liquid biofuels (e.g., bio-ethanol) and development of biorefineries (Scarlat et al., 2011; Kumar et al., 2021). Since biomass transportation costs influence the total biomass fuel costs, production site selection for new biomass facilities is an important factor when designing biomass supply networks (Awudu and Zhang, 2012; Yue et al., 2014; Atashbar et al., 2016). Numerous studies have focused on mathematical programming and simulation approaches to optimize bio-based supply chains and support decision making of biofuels or bioenergy production (Elia et al., 2011; Pérez-Fortes et al., 2012; You et al., 2012; Yilmaz Balaman and Selim, 2014; O’Neill and Maravelias, 2021). In such studies, besides the proximity factor between biomass resources and biofuel production plants, another factor that should be considered is the potential of using existing infrastructures for fossil-based fuel production. Potential benefits may arise from reductions in capital costs, shared utility infrastructures, and use of existing logistics networks. Moreover, a description of the employment effects, also for personnel in existing fossil infrastructures, from the construction and operation of biofuel supply chains can be found in the study of Yue et al. (2014).

Thus, the identification of synergies between the existing fossil infrastructure and liquid biofuel production can play a significant role toward a realistic gradual phase-out of fossil fuel production. However, on the technology level, most publications about liquid fuels production have focused either on facilities that can operate in isolation (Phillips et al., 2007; Hu and Lu, 2012; Dimitriou et al., 2018) or as parts of value chains for diverse biorefinery configurations (Parker et al., 2010; Sadhukhan et al., 2014; Karka et al., 2017; Doliente and Samsatli, 2020). This study, instead, focuses specifically on technological opportunities for "greening" conventional infrastructures with advanced biofuels processes based on lignocellulosic feedstock which are at a relatively high technology readiness level (TRL $>6)$. This can be a win-win situation, contributing to both a realistic, gradual phase-out of fossil infrastructures, and to increasing the TRL of biomass conversion technologies from demonstration to commercial scale facilities. This perspective also includes more generic options

\footnotetext{
${ }^{5}$ https://ec.europa.eu/jrc/en/jec/renewable-energy-recast-2030-red-ii ${ }^{6} \mathrm{https} / /$ ec.europa.eu/clima/policies/ets_en
} 
for integrating biomass toward a carbon-neutral energy sector, such as co-combustion and co-gasification of biomass and coal (Lainez-Aguirre et al., 2015; Puigjaner et al., 2015; Cintas et al., 2018). Thus, this study also includes steppingstone options, which may be especially relevant for regions with limited or no experience in biomass logistics. In this regard, a mapping of relevant European fossil-based and conventional facilities is also considered. This includes data for capacities of oil refineries, fossil-based power plants in Europe and potential of technologies that can be converted to produce liquid biofuels due to technical feasibility (e.g., biomass boilers converted to gasifiers). Each greening option is followed by a summary of the corresponding opportunities and barriers. This refers to economic, technological, and generic supply chain related factors which promote or impede the incorporation of these bio-based technologies in conventional infrastructures. Notwithstanding the importance of other factors, such as rigorous optimization of industrial site selection and supply chains as well as influence of national and international policies, such studies require detailed case-specific data, which lies outside the scope of the study. Instead, this study aims at providing the short- to mid-term perspectives for greening fossil infrastructures in the context of the most advanced biomass conversion technologies for liquid biofuels from lignocellulosic feedstock, based on an overview of the generic technology status, available capacities, and important techno-economic aspects.

\section{FRAMEWORK OF ANALYSIS}

In the framework of the current study, the possibilities for integrating biofuel production are divided in two categories, direct and indirect options, as shown in Figure 1.

1. "Direct" are characterized those technological options which lead to the incorporation of renewable carbon in the final molecule of the fuels. In practice, the substitution is achieved by:

- drop-in (blending) of a biogenic feedstock in a fossil-based process stream and then co-processing in a downstream conventional unit

- substituting a conventional part of the production chain of a liquid fuel by a bio-based one.

In both cases, the biogenic feedstock (or intermediate stream) can be produced, either within the system boundaries of the fossilfuel infrastructure or in a decentralized way and then transported to the fossil-fuel infrastructure for processing. According to Bunting et al. (2010) and DOE/EERE (2013) three possible insertion ways for biofuel to entry the petroleum infrastructure are identified: a bio-crude that can be co-processed with conventional crude oil, refinery-ready intermediates that are compatible with specific refinery streams for further processing at the refinery, and a near-finished fuel or blend stock that will be minimally processed at the refinery. The latter direct option is rather trivial from technology integration perspective, especially if it refers to pure mixing of the fuel product of a stand-alone biorefinery with the corresponding fuel of an oil refinery (e.g., mixing of bio-gasoline from the bio-methanol to gasoline process with oil refinery gasoline). As this case of greening refers to utilizing an existing fuel distribution-to-end-user infrastructure rather than the fossil fuel production infrastructure, it lies outside the focus of the present study.

2. "Indirect" are characterized those technological options which fall into one of the following two categories: steppingstone options which do not focus on the development of liquid biofuels infrastructures but on other energy related systems for short-term development of biomass supply infrastructures and mid-term potential of conversion to biofuel production, and other integration options which refer to the development of biomass supply infrastructures or liquid biofuels production through various non-fossil carbon-based industrial sectors such as 1st generation bio-ethanol plants, saw-mills and pulp and paper industry, and steel industry.

Figure 2 gives an overview of different routes from lignocellulosic biomass to fuel through various conversion technologies which refer to direct options and indirect options as described in Figure 1. Lignocellulosic biomass is one of the most abundant forms of biomass, including wood and residues from forestry, waste-wood from industry, agricultural residues such as straw and stover, and energy-crops such as willow or miscanthus. The various conversion technologies of biomass (Sims et al., 2010; Nanda et al., 2014; Sikarwar et al., 2017) can be roughly categorized in:

- Biochemical pathways, which include processes such as fermentation in which enzymes and other micro-organisms are used to convert cellulose and hemicellulose to sugars and alcohols.

- Thermochemical pathways including combustion, gasification, liquefaction, hydrogenation, and pyrolysis.

In the first category of biochemical pathways, the lignocellulosic ethanol pathway (also known as 2 nd generation ethanol) is the advanced biofuel technology with the higher TRL (IEA Bioenergy Report, 2020). However, it has only limited applications for integration with refinery infrastructures, mainly via utilities and logistics. Thus, despite the potential penetration of higher ethanol blending rates in the future (e.g., gasoline blending), heat integration with 1st generation ethanol plants is the main other integration options (i.e., categorized as indirect option in this study). Other options of lower TRL than those studied herein include the fermentation toward higher alcohols, the acetonebutanol-ethanol fermentation process being under ongoing research. The main target is to optimize the fermentation process and identify bacteria that maximize the butanol yields, which at the moment hinder the scale-up toward commercial scale for fuel relevant quantities. In general, fewer industrial actors are optimizing lignocellulosic production processes for butanol than for ethanol (IRENA, 2016).

In the second category of thermochemical pathways, bio-oil and syngas, as presented in Figure 2, are intermediate products for producing a wide range of fuels and chemicals through various processing paths (Canabarro et al., 2013). These two products provide opportunities for utilizing existing facilities, 


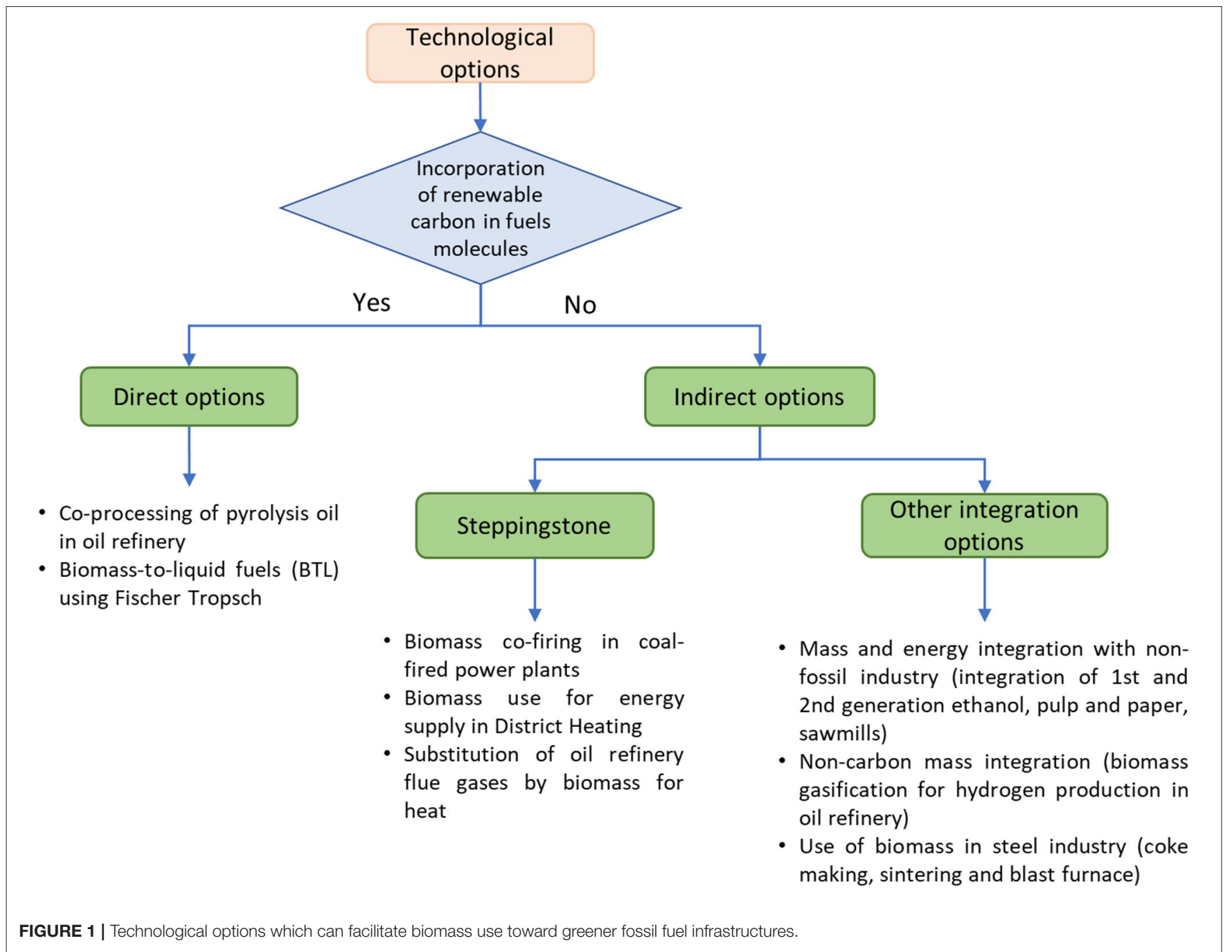

such as bio-oil hydrocracking, hydrotreating, gasification, and chemical synthesis. These intermediates can be produced within refinery sites or at other locations, for example in connection to existing power or combined heat and power plants (Cintas et al., 2018), which are considered points with potential to introduce biomass use.

The gasification-based pathways comprise synthesis reactions toward methanol, DME (Hannula and Kurkela, 2013), ethanol and higher alcohols (Villanueva Perales et al., 2011), liquefied methane (Thunman et al., 2018), and gasoline, diesel, and kerosene through FT synthesis (Swanson et al., 2010). Biomass gasification with FT synthesis [i.e., Biomass-To-Liquids (BTL) technology] can have a greening effect in oil refineries through FT syncrude co-processing and heat integration. The case of the substitution/conversion of Coal-To-Liquids (CTL) and Gas-ToLiquids (GTL) to BTL and combined feedstock options is also considered in this study.

In Figure 2, two conversion technologies are highlighted as direct options. The first is the case of biomass pyrolysis for coprocessing bio-oil in Fluid Catalytic Cracking (FCC) units. The pyrolysis-based pathways focus on the upgrading of pyrolysis oil via hydrotreatment and cracking toward gasoline, diesel, and kerosene, and liquefied methane. Thus, greening fossil infrastructures may refer to the partial substitution and blending of pyrolysis oil into existing oil refineries. The second is the case of syngas via gasification which can replace syngas from coal or natural gas for downstream FT synthesis. In addition, this path can provide waste heat in existing district heating $(\mathrm{DH})$ networks.

Hydrothermal liquefaction (HTL) is another thermochemical liquefaction process, alternative to pyrolysis, that produces biooil. Xing et al. (2019) and Sharma et al. (2020) studied the co-processing of HTL bio-oil with fossil fuels (e.g., VGO and straight-run gas oil, respectively). The study of Xing et al. (2019) showed that HTL bio-oils from woody biomass have significantly less oxygen (typically $<15 \mathrm{wt} \%$ ) than pyrolysis biooils and are more thermally stable, making them more amenable for co-processing in refining. Nevertheless, there is limited experience with processing HTL biocrudes, mostly because HTL technologies are in the transient state from lab-pilot scale to pilotindustrial scale (Gollakota et al., 2016). For this reason the HTL 


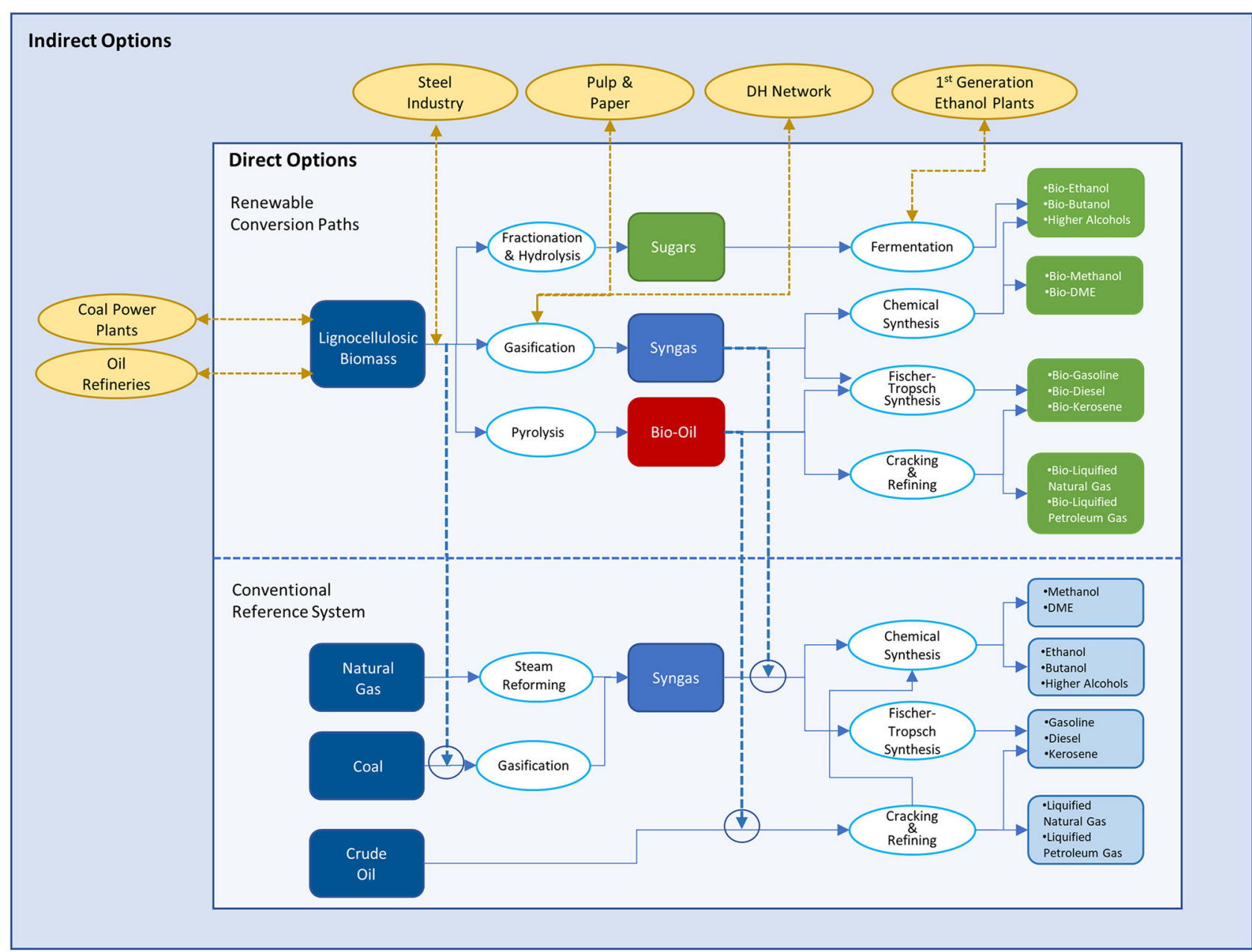

FIGURE 2 | Overview of different routes from biomass to fuel through various conversion technologies which refer to direct and indirect options.

pathway is not considered to satisfy the constraint of TRL $>6$ and it is not further studied herein.

Indirect steppingstone ways to implement greening of fossil infrastructures and enhance biomass use mainly refer to taking advantage of existing energy infrastructure of industrial facilities, onsite and offsite of power plants and combined heat and power plants, by starting with co-firing of biomass or by exploiting excess heat from biomass gasification plants in $\mathrm{DH}$ networks. The concept is that when the existing power plants using fossil feedstock are phased out (i.e., by other renewable energy sources), the sites can be partially or fully replaced by biomass pyrolysis, gasification, or other emerging biomass conversion technologies (e.g., HTL) for the production of intermediates which can be transported to refineries as analyzed by Cintas et al. (2018). To use existing infrastructure also includes taking advantage of existing knowledge and know-how on thermal processes as well as utilizing existing sites which keeps transportation costs low. Wherever it is difficult to build greenfield plants due to various constraints (e.g., financial, legal, technical, etc.), new biomassconversion plants could be built in already existing industrialized areas to benefit from existing process know how in energy plants and refineries.

\section{DIRECT OPTIONS FOR GREENING FOSSIL-FUEL INFRASTRUCTURES \\ Incorporation of Bio-Oil Feedstock Into Existing Oil Refineries}

Given that it is rather difficult to establish a specific way to provide a stable biomass feedstock (i.e., in terms of composition, properties, etc.), it is quite effective to transform it into bio-oil. However, bio-oil is reported to have high oxygen content ranging from 8 to $63 \%$ (dry basis) depending on feedstocks and pyrolysis conditions (Gollakota et al., 2016), with typical values ranging from 35 to $40 \%$ (dry basis) (Lehto et al., 2013), reducing the energy content of the fuel. Regarding further limitations of biooil use, it is rather immiscible with hydrocarbon fuels because of the high polarity of oxygenated compounds impeding it from direct use in the FCC process. Other relevant bio-oil properties 
are its chemical instability, low volatility, high viscosity, and corrosiveness. Nevertheless, the liquid nature of bio-oil is quite advantageous compared to handling solid biomass (Melero et al., 2012).

In terms of utilizing existing infrastructures, oil refineries can be suitable infrastructures for processing of bio-intermediate streams depending on the composition of the intermediate product. Many of the biocrudes may contain larger molecules of phenols, catechols, etc., which motivates co-processing in oil refinery units such as FCC, hydrocracker, or thermal cracking. However, the direct use of bio-oils in refineries by direct mixing with petroleum liquids is not technologically favorable and a way to tackle the insertion of bio-oils in a conventional refinery is by hydrotreating it. The hydrotreatment conditioning step results in partial hydrodeoxygenation (HDO) where the acidity and the oxygen content of the stream are reduced. Deoxygenation is applied up to a point which meets the minimum requirements of the refinery since approaching oxygen-free bio-oil can be expensive (van Dyk et al., 2019). Thus, the degree of HDO varies depending on the co-processing insertion point at the refinery (Karatzos et al., 2014). In this context, the PNNL study (Freeman et al., 2013) categorized US oil refineries in response to their conversion capability (i.e., ability to process biomass intermediates and convert higher boiling range into lower boiling range materials) which can be achieved through FCC or hydrocracking.

Co-processing of bio-oil in FCC together with vacuum gas oil (VGO) removes oxygen present in feedstocks in the form of water, $\mathrm{CO}$, and $\mathrm{CO}_{2}$ via simultaneous dehydration, decarboxylation, and decarbonylation. Co-processing in an FCC unit has an advantage compared to other processing units in a refinery as additional hydrogen or energy inputs are typically not required, saving both costs and additional GHG emissions. FCC is more profitable than thermal cracking and also minimizes the yield toward by-products such as gases, coke, and heavy fractions while maximizing the production of the liquid fraction suitable for use as transport fuel (Melero et al., 2012). Moreover, catalysts are more tolerant than hydrocracking catalysts in higher oxygen levels (Agblevor et al., 2012). The study of van Dyk et al. (2019) refers that hydrotreatment units are sensitive to oxygen and unlikely to be used to process bio-oils with an oxygen content that exceeds $5 \%$ at blending ratios of more than $10 \%$. It should be noted that there is limited experimental data on co-feeding of real bio-oils with petroleum feeds in hydrotreating units.

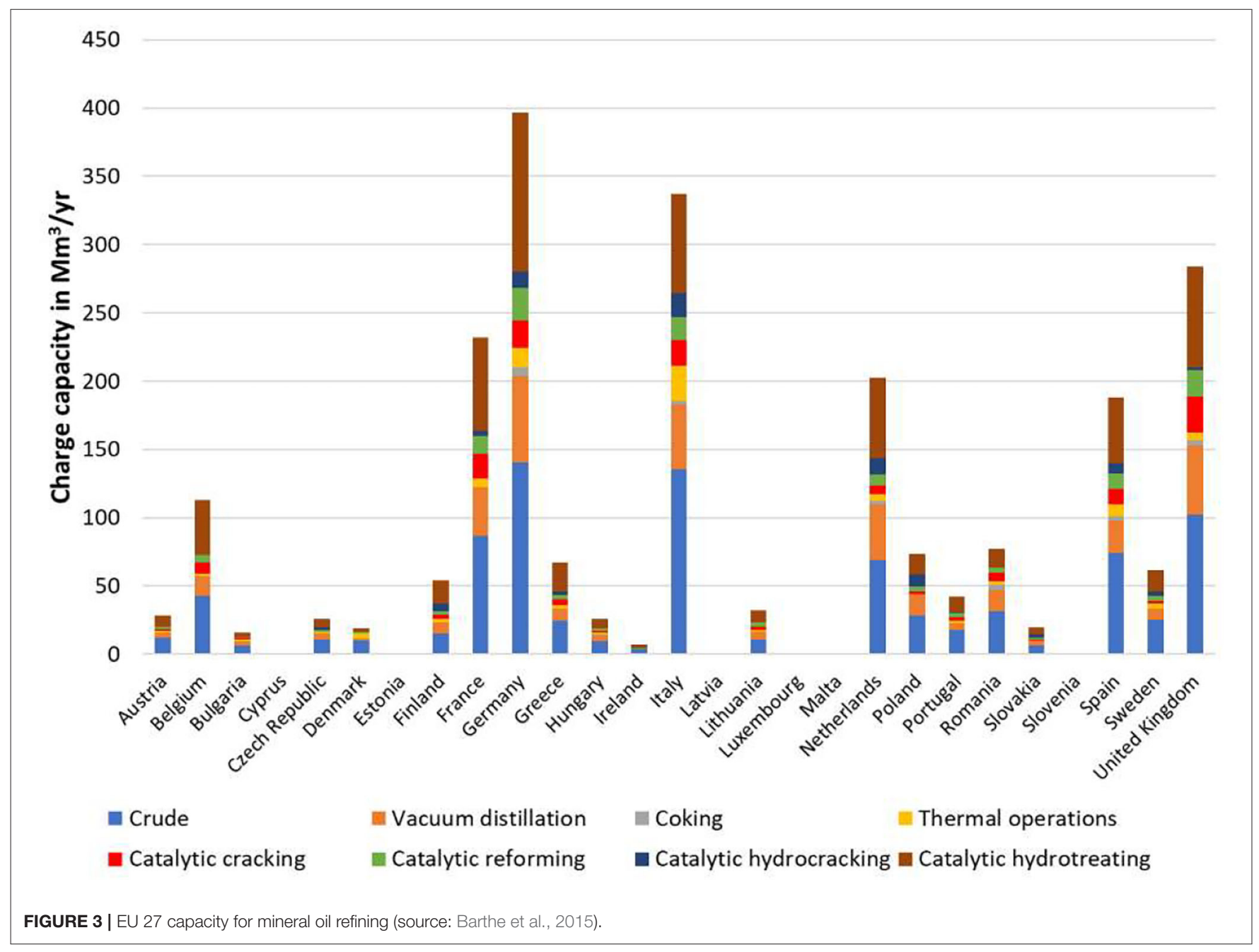




\section{Current Technology Status}

In contrast with the lack of commercial, lignocellulosic based fuels, which are basically at demonstration scale, the oleochemical route (e.g., feedstocks of vegetable oils and animal fats) to produce drop-in biofuels, is the most commercialized process. Oleochemical feedstocks due to their low oxygen content are easily converted to fuels (Melero et al., 2012), whereas lipid hydrotreatment has recently become a wellestablished technology with a few stand-alone operations (Neste, 2020). Even though this type of feedstock is out of scope for the particular study, some case studies are referred to herein as they can be considered as a good knowledge source about technological opportunities and constrains of coprocessing renewable feedstocks in oil-refineries. Some examples of hydroprocessing oleochemicals feedstocks in EU are presented in literature (de Jong and Jungmeier, 2015): Neste Oil operated since 2013 three Hydrotreated Ester and Fatty Acids (HEFA) facilities in Finland, Rotterdam, and Singapore with an annual total capacity of 2.4 billion liters of palm oil-derived diesel marketed as "NexBTL" (Neste, 2020). Preem (Sweden) has started to produce diesel $\left(330,000 \mathrm{~m}^{3}\right.$ diesel per year) with $30 \%$ renewable content (i.e., the renewable feedstock is raw tall oil, a byproduct from kraft pulp mills) in a modified mild hydrocracker unit (Sandén and Pettersson, 2013; Karatzos et al., 2014).

There are no cases of co-processing bio-oil in oil refineries at commercial scale. Stefanidis et al. (2018) discussed the possible insertion of bio-oil and biocrudes in the fluid catalytic cracker, whereas the increased coking and reactor plugging due to char and coke formation make upgrading of raw bio-oil through hydrotreatment necessary to remove oxygen. The results of this experimental set-up, of which the conditions did not resemble a real FCC, led to different conclusions when using a pilot-scale FCC under more realistic conditions. The same aspect of scaling up is discussed as a challenge in accurately predicting product distribution by Pinho et al. (2017), who presented an application of the use of lignocellulosic raw materials in a conventional refining scheme by the co-processing of raw bio-oils from pine woodchips with standard Brazilian VGO commercially processed in Petrobras FCC unit. In their study, two different bio-oil/VGO weight ratios were tested, 5/95 and 10/90. This pilot scale study was tested in a $200 \mathrm{~kg} / \mathrm{h}$ FCC demonstration-scale unit using a commercial FCC equilibrium catalyst and bio-oil was fed directly without any other pre-processing in order to test the sensitivity of production yields in diesel, gasoline, coke, $\mathrm{CO}$, and $\mathrm{CO}_{2}$. In all cases, about $30 \%$ of renewable carbon in pyrolysis oil ends up in total liquid products and bottoms.

\section{Potential for Integration Options of Oil Refineries With Biomass Use}

The refining sector in the EU comprises 85 refineries (according to data from years 2015-2016), spread across 22 Member States, Norway, and Switzerland. In total, EU has a combined throughput capacity of over $14.5 \mathrm{Mb} / \mathrm{d}$, accounting for roughly $14.5 \%$ of global refining capacity in 2015. Overall, the sector exhibits a wide variety in levels of configuration, integration, and production with capacity ranges between 40 and 425 $\mathrm{Kb} / \mathrm{d}$. Europe's largest refineries $(>250 \mathrm{~Kb} / \mathrm{d})$ are located in the
Netherlands, Poland, Germany, Belgium, Italy, UK, and Spain (Nivard and Kreijkes, 2017).

According to the data provided by Nivard and Kreijkes (2017), the oil refineries, spread across 22 of the EU Member States, Switzerland, and Norway are mainly developed near major seaports, large rivers or pipelines. The distribution in terms of number of refineries is more even across EU compared to refining capacity which is more concentrated in the North-Western part of the EU close to the North Sea crude oil sources (European Commission, 2016a,b,c).

Since most refineries in the EU are equipped with FCC units according to the values for oil refinery installations for 2013, these units can be considered as a potential infrastructure for coprocessing pyrolysis oil (Barthe et al., 2015). Figure 3 presents various processing techniques of the European oil refineries (EU 27 ) and the existence of FCC per country indicates a potential of co-processing bio-oil. Of course, many other factors may play significant role in the application of this "greening" possibility such as supply chain infrastructures, policies which enhance the development of renewable infrastructures, technological constraints, and the existence of financial support instruments.

According to the reported ranges of $2-10 \%$ of blending biooil in FCC units (where the 10\% would refer to the case of HDO bio-oil) an estimation of the potential HDO bio-oil is possible. The potentially used HDO bio-oil would be approximately 10 $\mathrm{Mm}^{3}$ /year HDO to be blended in the FCC units for the whole FCC capacity in Europe. This corresponds to approximately 6,400 MW bio-oil production (e.g., 64 plants in Europe of $100 \mathrm{MW}$ each). This would require 10,000-11,000 MW of lignocellulosic biomass (e.g., woody residues) in total in Europe to be converted in this bio-oil. These estimations are based on LHV of approximately $20 \mathrm{MJ} / \mathrm{l}$ for bio oil and a blend ratio of $10 \%$.

\section{Bio-based Syngas for Liquid Fuels (BTL) Including Fischer-Tropsch Synthesis}

The gasification pathway via the intermediate synthesis gas utilizes technologies already commercialized for production of methanol, diesel, and jet from natural gas and coal. Synthesis gas conversion to methanol is very well-established in the chemical industry, methanol being mainly reported as a fuel in marine applications in the form of blends (10\% in methanol) (Paulauskiene et al., 2019) or in light and heavy duty vehicles (e.g., in China) (Schröder et al., 2020). Using synthesis gas with FT synthesis to produce liquid hydrocarbons, where crude oil is not readily available, is also well known for exploiting coal or natural gas resources (Gudde et al., 2019). Thus, it is the synthesis gas production and cleaning via biomass gasification technology that determines the performance of the BTL pathways compared to gasification of other resources or natural gas steam reforming (Dimitriou et al., 2018).

\section{Current Technology Status}

Several CTL and GTL FT plants are running or planned, while biomass-based conversion for production of FT fuels is only at pilot or demonstration scale (Luque et al., 2012). The FT process is currently being operated at an industrial scale by two 
main fossil fuel companies: Sasol in South Africa (producing 160,000 bpd of FT-diesel from coal derived syngas and converting of one of its CTL facilities to accept natural gas) and Qatar (34,000 bpd Oryx GTL facility) and Shell ${ }^{7}$ in Malaysia [world's first commercial-scale Gas-To-Liquid (GTL) plant based on FT synthesis producing $15,000 \mathrm{bpd}$ of middle distillates and specialty products] and Qatar (in collaboration with Qatar Petroleum producing 260,000 barrels of GTL products).

Over the last several decades, a continuous effort to improve catalyst activity, selectivity, and stability has been carried out in these fossil-based GTL and CTL technologies. Thus, similar challenges should be expected for BTL technologies utilizing FT synthesis with respect to the suitability of biomass syngas using the existing catalysts (Luque et al., 2012). It should be noted that data from FT plants mostly come from engineering studies or cost estimates for plants currently under construction or commissioning according to IEA Bioenergy Report (2020). It has been suggested that when a BTL process is compared to a GTL one, the main challenges are related to processing a more heterogeneous biomass feedstock, production of a lower quality syngas, and the feedstock availability risks (Hileman et al., 2009).

\section{Potential Integrations With Fossil Infrastructures}

While the FT process does not depend on how the syngas is produced, as long as its composition depending on the feedstock fulfills the downstream specifications, the gasification technology is the key technological step to the integration of CTL and BTL processes. In order to take advantage of the economy of scale when using biomass, significant efforts are being made to test CBTL processes, namely co-gasification of coal and biomass (Shah, 2013).

Even though GTL and CTL have reached commercial scale, the BTL process has not been completely commercially established. There are various examples of pilot and demonstration plants or discontinued BTL projects in Europe, such as the Choren Carbo-V!Process producing light FT products (now out of operation) in Frieberg Saxony in Germany and the BioTfuel pilot project in France which produces biodiesel and biokerosene based on biomass gasification (ETIP bioenergy ${ }^{8}$, Biofuels Barometer, 2017).

NSE Biofuels Oy operated a $12 \mathrm{MW}_{\text {th }}$ (656 tons/year of fuels) BTL demonstration plant in Finland from 2009 to 2011, which employed a circulating fluidized bed (CFB) gasifier developed by Foster Wheeler (Dimitriou et al., 2018). The GoBiGas plant in Sweden, which is a first-of its-kind industrial installation for advanced biofuel production via gasification, converted woody biomass to biomethane (Thunman et al., 2018, 2019). These plants can be considered as a proof-of-concept for the production of liquid biofuels via gasification.

Biomass gasification process is usually limited to small scale due to biomass availability and logistics constraints, negatively influenced by seasonality, moisture, and low density, unlike coal

\footnotetext{
${ }^{7}$ Shell. https://www.shell.com/about-us/major-projects/pearl-gtl/the-world-slargest-gas-to-liquids-plant.html

${ }^{8}$ https://www.etipbioenergy.eu/value-chains/conversion-technologies/advancedtechnologies/biomass-to-liquids
}

and natural gas. Thus, biomass gasification processes tend to have high capital (fixed) cost, present lower thermal efficiency than coal-fired plants, and are subject to long term supporting policies. Their theoretical optimum capacity is frequently limited by biomass logistics issues.

The mixture of coal and biomass in co-gasification could be a steppingstone measure to develop biomass facilities in case of CTL existing infrastructures; however, the CTL technology is generally lacking in EU countries. Success stories of co-gasification is the NUON power plant at Buggenum (Netherlands) and Schwarze Pumpe (Germany), in which large proportions of biomass and coal have been co-gasified for liquid fuel and syngas (Kamble et al., 2019; IEA Bioenergy Agreement, Task $33^{9}$ ). This integration option provides a stable and reliable feed supply and potential feedstock disturbances of biomass supply cause less consequences in the production (Shah, 2013). NERL (National Energy Technology Laboratory) reported that the use of $30 \%$ switchgrass with coal for producing diesel (CBTL) with carbon capture and storage technology (CCS) produced 63\% less GHG emissions compared to a fossil-derived diesel. Greenhouse gas emissions can further be decreased up to $75 \%$ by using more aggressive capturing technique of auto-thermal reformer in CCS (Brar et al., 2012).

Representative disadvantages of co-gasification are feed preparation and complex feed systems which can be expensive. The choice of gasifier operation parameters (temperature, gasifying agent, and catalysts) determine product gas composition and quality. Biomass decomposition occurs at a lower temperature than coal and, therefore, different reactors (fluidized bed or downdraft gasifier) compatible to the feedstock mixture are required. Also, at high temperature, alkali present in biomass can cause corrosion problems in downstream pipes. Biomass containing alkali oxides and salts with ash content above $5 \%$ causes clinkering/slagging problems (Brar et al., 2012).

The Concawe Report (2020) gives some numerical estimations and order of magnitude analysis regarding the potential quantities of biomass requirements and liquid products in the case of co-feeding a conventional gasifier of an oil refinery with a renewable feedstock. In EU only 6 refineries have been reported with gasifiers which convert residual oil to syngas for further production of methanol, hydrogen, and power and can be considered as potential points for biomass co-feeding. The estimations of Concawe report consider the case of a largescale refinery-based gasifier which consumes $\sim 1 \mathrm{Mt} / \mathrm{a}$ of residue and point out that such a modification to receive biomass or bio-intermediate streams for units of this scale is a challenging matter. If a gasifier of that scale (i.e., $\sim 1 \mathrm{Mt} / \mathrm{a}$ ) is co-fed with $5 \%$ biomass, thus requiring $\sim 50 \mathrm{kt} / \mathrm{a}$ of biomass, this can result in a rather small quantity of $25 \mathrm{kt} / \mathrm{a}$ of liquid product, whereas higher co-feeding ratios up to $50 \%$ would be a matter of significant technological and economic challenges (Gudde et al., 2019).

Table 1 summarizes the aforementioned direct options of biomass to liquid fuels in existing fossil infrastructures. The options are characterized with respect to opportunities and

${ }^{9}$ IEA Bioenergy Agreement: Task 33, Thermal gasification of biomass. task33.ieabioenergy.com 
TABLE 1 | Direct integration options of biomass to liquid fuels in fossil infrastructures.

\begin{tabular}{|c|c|c|c|c|c|}
\hline Integration option & Opportunities & Barriers & Real world examples & References/Supplementary data & $\begin{array}{l}\text { Feasibility to scale up } \\
\text { (low, medium, high) }\end{array}$ \\
\hline $\begin{array}{l}\text { Bio-oil } \\
\text { co-processing within } \\
\text { an oil refinery }\end{array}$ & $\begin{array}{l}\text { Technological } \\
\text { - TRL of biomass pyrolysis: } 6 \text { or } \\
\text { higher ETIP Bioenergy, } 2020 \\
\text { Economic } \\
\text { - Co-processing bio renewable } \\
\text { feeds and fuels in existing } \\
\text { refinery units is more profitable } \\
\text { than the stand-alone case } \\
\text { Jones et al., 2009; Beims } \\
\text { et al., 2017; Bhatt et al., } 2020 \\
\text { Supply chain } \\
\text { - Established infrastructure of } \\
\text { refineries for long-distance sea } \\
\text { transport } \\
\text { - Bio-oil imports can be } \\
\text { facilitated together with oil } \\
\text { imports Doug, 2006; Cintas } \\
\text { et al., } 2018\end{array}$ & $\begin{array}{l}\text { Technological } \\
\text { - Current blending ratios of } \\
\text { 2-10\% lead to rather low } \\
\text { scaleup feasibility } \\
\text { Directorate-General for } \\
\text { Mobility Transport, } 2018 \\
\text { - Presence of water and } \\
\text { oxygenated organic } \\
\text { compounds affects yields and } \\
\text { conversion rates Air } \\
\text { Resources Board, } 2017 \\
\text { - Alkali metals deactivate FCC } \\
\text { catalysts Air Resources Board, } \\
\text { 2017; Pinho et al., 2017 } \\
\text { - Differences in yields when } \\
\text { scaling-up from pilot to } \\
\text { commercial scale projects } \\
\text { Pinho et al., } 2017 \text {; Stefanidis } \\
\text { et al., 2018 } \\
\text { Economic } \\
\text { - Co-processing is highly } \\
\text { sensitive to the crude prices } \\
\text { and refinery feed rates } \\
\text { Supply chain } \\
\text { - Discontinuous production, } \\
\text { variety and storage of biomass } \\
\text { feedstock transportation } \\
\text { chains, required pretreatments } \\
\text { to accomplish energy } \\
\text { densification } \\
\text { - Challenge of the decentralized } \\
\text { production of pyrolysis oil and } \\
\text { its transfer to the oil refineries } \\
\text { as the physical properties } \\
\text { change during storage and } \\
\text { transportation Yang et al., } \\
2015\end{array}$ & $\begin{array}{l}\text { - IEA Bioenergy Agreement, } \\
\text { Task 39a } \\
\text { - Petrobras/NREL CRADA } \\
\text { international partnership } \\
\text { - Co-processing of pine-based } \\
\text { bio-oil with petroleum-based } \\
\text { fuel intermediate oil in the } \\
\text { fluidized catalytic cracking } \\
\text { process (FCC) } \\
\text { - No other commercial case } \\
\text { studies exist, just } \\
\text { demonstration cases } \\
\text { - Other cases but not from } \\
\text { pyrolysis of lignocellulosic } \\
\text { feedstock Biodiesel } \\
\text { production from tall oil (a } \\
\text { byproduct of the kraft } \\
\text { processing of pinewood for } \\
\text { pulp and paper), as a result of } \\
\text { co-processing in oil refinery } \\
\text { (https://www.etipbioenergy.eu/ } \\
\text { value-chains/feedstocks/ } \\
\text { waste/tall-oil) }\end{array}$ & $\begin{array}{l}\text { - Capacities of all European refineries: (Nivard } \\
\text { and Kreijkes, The European Refining Sector: A } \\
\text { Diversity of Markets?, 2017) } \\
\text { - Data for FCC units Barthe et al., } 2015 \\
\text { - Other research studies suggesting co-processing } \\
\text { of up to } 20 \% \text { wt bio-oil with VGO in FCC units } \\
\text { Fogassy et al., } 2010 \\
\text { - Example of estimation of co-processing and } \\
\text { production of bio-renewable fuel potential in } \\
\text { California Air Resources Board, } 2017 \\
\text { - Study of co-locating a plant of hybrid poplar for } \\
\text { gasoline and diesel production from fast pyrolysis } \\
\text { with an existing refinery in the USA including } \\
\text { capital investment data Jones et al., } 2009 \\
\text { - Co-location of fast pyrolysis with an oil refinery to } \\
\text { eliminate the need for pressure swing adsorption } \\
\text { unit in the hydrotreating unit, with off-gas from } \\
\text { hydrotreater being sent to refinery hydrogen } \\
\text { generation } \\
\text { - Economic analysis of co-processing bio-oil in an } \\
\text { FCC unit in petroleum refinery Ali et al., } 2018\end{array}$ & $\begin{array}{l}\text { - } \text { Low }^{\text {b }} \text { (with respect to } \\
\text { the technologies of } \\
\text { upgrading bio-oil to } \\
\text { advanced liquid fuels, } \\
\text { both in a fully integrated } \\
\text { plant or by } \\
\text { co-processing with } \\
\text { fossil fuels, typically } \\
\text { validated at lab scale, } \\
\text { reaching TRL 4-6) }\end{array}$ \\
\hline
\end{tabular}


TABLE 1 | Continued

\begin{tabular}{|c|c|c|c|c|c|}
\hline Integration option & Opportunities & Barriers & Real world examples & References/Supplementary data & $\begin{array}{l}\text { Feasibility to scale up } \\
\text { (low, medium, high) }\end{array}$ \\
\hline $\begin{array}{l}\text { Biomass-to-liquid } \\
\text { fuels (BTL) via } \\
\text { Fischer-Tropsch }\end{array}$ & $\begin{array}{l}\text { Technological } \\
\text { - Co-gasification of biomass } \\
\text { and coal can build upon } \\
\text { experience for biofuels } \\
\text { production } \\
\text { - Fischer-Tropsch (FT) synthesis } \\
\text { is an established technology, } \\
\text { and many components are } \\
\text { mature in CTL and GTL plants } \\
\text { - Gasification plants can reach, } \\
\text { after modifications, theoretical } \\
\text { efficiency yields in commercial } \\
\text { scale and have achieved } \\
\text { continuous operation } \\
\text { Economic } \\
\text { - Technical advances in the FT } \\
\text { process regarding yield and } \\
\text { conditions can make biofuels } \\
\text { competitive depending on } \\
\text { crude oil prices Luque et al., } \\
2012\end{array}$ & $\begin{array}{l}\text { Technological } \\
\text { - A fully scaled-up commercial } \\
\text { BTL process is not completely } \\
\text { established until today. Luque } \\
\text { et al., } 2012 \\
\text { - Application of the } \\
\text { corresponding process using } \\
\text { biomass has yet to be fully } \\
\text { optimized } \\
\text { - Gasification technologies } \\
\text { require development, } \\
\text { especially regarding feedstock } \\
\text { pretreatment and logistics } \\
\text { Economic } \\
\text { - Cost of feed preparation and } \\
\text { logistics of biomass for an } \\
\text { optimum size of a BTL plant } \\
\text { can become an important } \\
\text { factor in the scale of BTL } \\
\text { process } \\
\text { - No tax for fossil fuels and high } \\
\text { production costs impede } \\
\text { biofuel to be competitive } \\
\text { - Fixed cost for BTL plant is } \\
\text { generally } 60 \% \text { higher than the } \\
\text { one required for GTL plant of } \\
\text { the same size Lee, } 2013 \\
\text { Supply chain } \\
\text { - Biomass is difficult to transport } \\
\text { and store } \\
\text { - No consistent supply }\end{array}$ & $\begin{array}{l}\text { - The case of Sweden's } \\
\text { GoBiGas plant which is a } \\
32 M W_{\text {th }} \text { gasifier and produces } \\
\text { SNG. Potential scaling up in } \\
\text { 200MW could produce liquid } \\
\text { fuels Thunman et al., } 2018\end{array}$ & $\begin{array}{l}\text { Database of facilities for the production of } \\
\text { advanced liquid and gaseous biofuels for } \\
\text { transport per country and TRL (https:// } \\
\text { demoplants.bioenergy2020.eu) } \\
\text { - The capital cost estimates for a first-of-its-kind } \\
\text { commercial gasification-based facility (2000 tons } \\
\text { of biomass (dry basis) per day) are in the region of } \\
\text { USD } \$ 600-900 \text { million which is favored from } \\
\text { economies of scale Karatzos et al. (2014) } \\
\text { - Overview of FT units in EU countries (Luque } \\
\text { et al; 2012) } \\
\text { - The size of FT process depends on the size of the } \\
\text { gasifier for an integrated process. For example, a } \\
\text { BTL plant producing } 2,100 \text { bbld will require a } \\
\text { gasifier producing } 250 \mathrm{MW}_{\text {th }} \text { Lee, } 2013\end{array}$ & $\begin{array}{l}\text { Lowc (with respect to } \\
\text { scaling up gasification) }\end{array}$ \\
\hline
\end{tabular}

aIEA Bioenergy Agreement, Task 39. https://demoplants.bioenergy2020.eu/.

${ }^{b}$ Based on the argument that significant challenges need to be resolved such as matching the scale, sizing and catalyst design for two distinctly different feedstocks [bulky and reactive solid biomass versus relatively inert petroleum liquids (crude oil)].

${ }^{c}$ Due to biomass related infrastructures for processing and logistic issues. 
barriers for integration together with real world examples with some references. For the bio-oil processing, the most important constraints are the upgrading steps of bio-oil (catalyst deactivation and high oxygen content) even though pyrolysis is a well-established technology. Economic parameters are also important in implementing this upgrading and require minimum capital costs to retrofit petroleum refinery units in order to be compatible with the insertion points (Tong et al., 2013a,b). Regarding the BTL processes, FT is an established technology, and many components of the system are already technologically mature in CTL or GTL plants. What remains unproven is the BTL processes at a commercial scale due to technical barriers of gasification and scale up constraints. The overall greening impact is further restricted by the significantly smaller capacities of FT plants compared to oil refineries.

With respect to the supply chain barriers of these solutions, which are mainly related to the potential variability of the biomass feedstock in quantity and quality, it should be noted that these greening opportunities of the existing infrastructure are advantageous compared to newly built stand-alone biofuel plants. The reason is that such stand-alone plants would have to be considerably oversized, at least in the first phase of their operation, to reduce the risk of interruption in sellable products. Obviously, this risk is inherently reduced when the biofuel plants are integrated into existing operating facilities. In general, an important factor related with using the opportunities and overcoming barriers in Table $\mathbf{1}$ is related with regional and international policy support, including financial instruments.

A successful deployment of liquid biofuels plants can be achieved on the basis of a holistic approach able to identify technical, economic, and supply chain related challenges and the policy gaps to overcome these challenges. Thus, a set of policy interventions including regulations, financing, and information provision mechanisms can better capture the different challenges along the biomass value chains and allow optimizing performance for all stages. This policy dimension lies outside of the scope of the current analysis, as more detailed information can be found elsewhere (ADVANCEFUEL, 2020a,b; Panoutsou et al., 2021; Singh et al., 2021).

Another barrier, outside of the scope of the current analysis, is the challenges related to the plant-to-end user distribution network of liquid biofuels and the availability of the adequate infrastructure. Fuels such as 1st generation ethanol present incompatibility with fossil fuels in common supply systems such as pipelines and require dedicated fuel distribution systems. On the other hand, drop in fuels would gain easier market acceptance whereas a challenging point is their integration with petroleum refineries in terms of capacity expansion and efforts to coordinate with fossil production (Yue et al., 2014).

\section{INDIRECT OPTIONS FOR GREENING FOSSIL-FUEL INFRASTRUCTURES-STEPPINGSTONE OPTIONS}

The following paragraphs describe two indirect steppingstone options: integration of biofuels production in $\mathrm{DH}$ networks and co-firing of biomass and coal for power production. These two options enhance the biomass supply conditions for the development of logistics for liquid biofuels or they can lead to higher system efficiency from biofuels plants in the case of potential integration schemes (e.g., retrofitting of existing $\mathrm{DH}$ boilers in gasifiers).

\section{Integration of Biofuel Production Into Existing District Heating Infrastructure}

This option refers to the case of biomass gasification with subsequent synthesis to biofuels such as FT diesel, DME, methanol, and methane. This option prerequisites the existence of a $\mathrm{DH}$ network. In this case, these biofuel plants generate excess heat and energy efficiency can be succeeded if using the excess heat in DH systems. Therefore, heat integration of biofuel plants with $\mathrm{DH}$ networks can improve the economic and environmental performance of the integrated system, especially when replacing decommissioned heat generation capacity for existing DH systems or when investments are made to extend the $\mathrm{DH}$ systems. Broad implementation of gasification-based biofuel production in European DH systems is discussed by Berndes et al. (2010), who concluded that a heat source-sink matching between the excess heat from biomass gasification plants for the production of transport biofuels according to the EU 2020 target and the DH systems in EU is not subject to any sink constraints (i.e., the heat sink of the $\mathrm{DH}$ systems would be in this case more than sufficient).

\section{Current Technology Status}

As fossil fuels dominate the energy supply for $\mathrm{DH}$, there is a strong potential for the transition in other renewable sources such as biomass. The Swedish example represents the gradual incorporation of biomass in existing infrastructures and highlights the possibility for the development of infrastructures for the production of liquid biofuels (e.g., the case of GoBiGas plant as reported by Thunman et al., 2018) which can be favored from the existence of a DH network.

District heating supplies $12 \%$ of space heating and domestic hot water demand for buildings in EU. From 1990 until 2015, the use of gas was expanded contributing to around $1 / 3$ of the total DH supply whereas, during the same period, biofuels use expanded its share to $20 \%$ and renewables account for $6 \%$ of the DH production (Mathiesen et al., 2019). In 2015, the total heat supplied to EU DH was 2.3 EJ, of which around $30 \%$ of the DH supply came from coal and coal products, $4.5 \%$ from oil, 35\% from natural gas, $26 \%$ from biomass and waste, and $4.5 \%$ from other sources (Werner, 2017). Regarding the technology providing this amount of heat to the $\mathrm{DH}$ system, this is mainly produced (54\%) from recycled heat, fossil CHP, and industries, $19.5 \%$ from recycled heat and renewable CHP, $9 \%$ from renewables (geothermal and waste), and 17.5\% from fossil direct use (fossil boilers). The value of heat supply from fossil boilers corresponds to $0.4 \mathrm{EJ} /$ year (or equivalently to 111 TWh/year) and the scenario of replacing them by heat from biomass gasifiers is analyzed in the section Potential Future Applications of DH Based on Biofuel Plants.

To this end, one should also consider the competition from excess heat from other major industrial sectors. Heat Roadmap 
Europe $2050^{10}$ provides information per country for major industrial plants regarding five typical energy intensive industrial sub-sectors having excess heat, namely chemical/petrochemical, iron and steel, non-ferrous metals, non-metallic minerals, pulp, and paper production and oil refineries. An overview of these heat streams for 2008 indicates 0.3 TWh in France, 4.9 TWh in Sweden, 0.8 TWh in Denmark, 0.9 TWh in Germany, and 0.03 TWh in Italy. These volumes add up to approximately 6.9 TWh for EU27. Moreover, the Stratego project (http://strategoproject.eu) provides a sectoral analysis within which fuel supply and refineries represent highest annual excess heat availabilities (9\% of the total excess heat volume and $36 \%$ of total industrial sectors volumes), while non-metallic minerals facilities account for $5 \%$ of the total excess heat volume and $20 \%$ of total industrial sectors volumes.

\section{Potential Future Applications of DH Based on Biofuel Plants}

Introducing biomass in $\mathrm{DH}$ will create a supply system which later may be used for biofuels plants for transportation. The aforementioned study of Berndes et al. (2010) illustrated the size of the current DH systems in EU25 in relation to the EU biofuels for transportation targets for 2020. It was calculated that if $10 \%$ of the projected transport energy demand in EU by 2020 was to be met with biofuels from biofuel production units integrated in the DH system, and that these would deliver 0.2 energy units of DH heat per energy unit of biofuel produced, these biofuel plants would cover roughly $15 \%$ of the total heat demand in the current DH systems in EU25.

This statement could be applied in the case of biofuels contribution to the transport energy mix for 2030 and 2050 according to the scenarios developed in the framework of the ADVANCEFUEL project (ADVANCEFUEL, 2020a,b, http:// www.advancefuel.eu/) and the European Commission (2018). According to the previous profile of technologies supplying heat to $\mathrm{DH}$, it is assumed that fossil boilers, accounting for approximately $111 \mathrm{TWh} /$ year in European DH systems, are decommissioned and they are replaced by biomass gasifiers. In the framework of ADVANCEFUEL, a scenario is formulated assuming a strong growth of biofuels and a breakthrough of advanced biofuels in the transport sector and a low diffusion of electric vehicles. This scenario corresponds to maximum penetration of liquid biofuels in the transportations sector, and thus it is useful to analyze potential excess heat to heat sink constraints, with respect to the DH capacity. In this scenario, the installed capacity of biofuels production is assumed to be around $44 \mathrm{GW}$ in 2030 and up to almost $191 \mathrm{GW}$ in 2050, with large roles for bioethanol and alcohol-to-jet fuel (19\% of installed capacity in 2030 and 33\% in 2050) and thermochemical production routes ( $40 \%$ of installed capacity in 2030 and $58 \%$ in 2050). If, the thermochemical production is considered as a source of liquid biofuels, then 17.6 GW (154 TWh/year) of fuels from thermochemical route are produced. If $20 \%$ of this energy can be delivered to DH network (Berndes et al., 2010), 30.8 TWh/year would be provided as excess heat. Accordingly, for

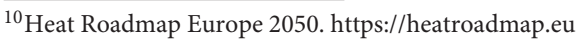

2050, $110 \mathrm{GW}$ (964 TWh/year) would be produced and assuming that $20 \%$ of this energy can be delivered to DH network, 192.8 $\mathrm{TWh} /$ year can be delivered to the DH network.

According to another baseline scenario reported for the EU transportation mix in 2050 (European Commission, 2018), liquid biofuels consumption is projected to be $6 \%$ of the total fuels consumed. This results in $188 \mathrm{TWh} /$ year of liquid biofuels consumption with a potential of providing at maximum 37.6 $\mathrm{TWh} /$ year excess heat to DH network, if all the liquid biofuels come from thermochemical biomass conversion technologies. Other scenarios of this report for more extended penetration of liquid biofuels in the transportation mix, result in heat delivered ranging between 58.2 and $110 \mathrm{TWh} /$ year. All these values for heat delivered to the $\mathrm{DH}$ network are directly comparable to the value of $111 \mathrm{TWh} /$ year which is the current heat supplied by fossil boilers, as well as to the $6.9 \mathrm{TWh} /$ year which is the currently available excess heat from the main industrial sectors in EU. The comparison clearly shows that for most of these scenarios the DH system has presently more than the required capacity to be efficiently used as heat sink for the excess heat from future biofuel production. This is also not constrained by the competition with industrial excess heat. These conclusions are also in agreement with the argument of Berndes et al. (2010). Only the scenario of the ADVANCEFUEL project for maximum penetration of liquid biofuels in 2050 with limited use of electricity in the transportation mix results in an excess of this $\mathrm{DH}$ system capacity (i.e., $192.8 \mathrm{TWh} /$ year compared to $111 \mathrm{TWh} /$ year, respectively). However, the corresponding liquid biofuel production of this scenario should be considered as a theoretical maximum since limited use of electricity in the transportation is not currently considered as a very likely scenario.

Thus, replacing part of the fossil boilers for DH systems by biomass boilers, with the intention of converting these biomass boilers later into gasification systems for biofuel production with simultaneous use of the excess heat for DH systems to increase the overall system efficiency, is a promising steppingstone option. Of course, the potential of this integration option may be reduced if the competitiveness against other heat supply technologies is considered (e.g., CHP systems which currently dominate the DH heat supply in most Member States). Another aspect that can affect the economic feasibility is the extent to which the DH integrated biofuel plant becomes a base load heat provider for the DH system (Berndes et al., 2010).

The study of Thunman et al. (2018) presents a potential strategy of how fluidized bed boilers can be retrofitted to biomass gasifiers which can then be operated for integrated production of fuels with DH systems heat delivery. As an example, the fluidized boilers [CFB and bubbling fluidized bed (BFB)] currently installed in the Swedish energy system can be operated as Dual Fluidized Bed (DFB) gasifiers. This scenario represents a lowcost, low risk option for large penetration of biofuel production. Retrofit of biomass boiler for combined production of electricity and $\mathrm{DH}$ to a gasifier with upgrading synthesis steps would reduce investment cost by 10-20\% compared to a new stand-alone plant. But equally important, this is an example of how the existing energy infrastructure, including knowledge and competence, could be utilized for fast introduction of biofuel production. 
Thunman et al. (2018) presented the potential in a numerical estimation: to the $6,400-\mathrm{MW}_{\text {th }}$ installed boilers, the required boiler capacity that needs to be added is $6,800 \mathrm{MW}_{\text {th }}$ to create a gasification potential of $35,000 \mathrm{MW}$. This correspond to a fuel demand of 280 TWh of biomass or equivalently 59 million dry tons of biomass per year $(8,000 \mathrm{~h}$ annual operation), which can produce between 170 and 200 TWh (14.6-17.2 MTOE) of advanced biofuels. This is significantly greater (i.e., about 5 times) than the Swedish target for biofuel production required to reach the Swedish goal of fossil free nation in Year 2045. Considering logistic constraints lowers this potential. Thus, for most locations it is not feasible to have units with fuel inputs $>500 \mathrm{MW}(2,500$ dry tons of biomass/day) which lowers the annual potential fuel demand by around $30 \%$ (i.e., to 200 TWh or equivalently 42 million dry tons of biomass). This is, nevertheless, a substantial demand for fuel (i.e., approximately equal to the total forest growth in Sweden), implying that biomass must be imported if this scenario is to be realized. In other words, there is a low risk option for introduction of biofuel production to an extent that is in fact the national biomass supply, which limits the amount of fuel production even if Sweden has large amounts of forestry derived biomass.

The Refuel project (Berndes et al., 2008) suggested criteria for a country to be candidate for introducing cogeneration of BTL fuels and heat for DH such as the existence of a large and possibly expanding DH system and a presently small share of heat from renewable and recyclable heat. Indicatively, Poland and Slovenia were proposed as the most interesting for introducing co-generation of BTL fuels and heat due to their high use of coal and oil, whereas Italy, France, UK, and Belgium were considered as countries that is easier to introduce the BTL fuels integrated with the $\mathrm{DH}$ option in a system that is expanding.

It should also be noted that establishing a biomass supply chain for providing heat as steppingstone is not restricted to $\mathrm{DH}$ systems. Another strategy is to incorporate biomass use in the form of biomass boiler infrastructure in oil refineries, where there is a large steam demand that is currently covered by combusting the gases produced from the internal distillation or conversion processes. The composition of these gases is similar to the one of gases produced in a biomass gasifier and can be mixed for fuels production. Thus, a low cost and low risk option is to install a biomass boiler for part of steam production. This first step of greening the fossil-based refinery infrastructure aims to increase gradually the demand for biomass and to build up the logistic infrastructure needed to receive biomass at the plant by starting with the installation of a CFB boiler. After the development of an established biomass infrastructure is accomplished, the CFB boiler can be later upgraded in a biomass gasification system through its connection to a BFB boiler in the form of an indirect dual-bed gasifier.

\section{Biomass Co-firing With Coal}

This is included as an indirect option since biomass co-firing is a low risk option to produce renewable electricity (and heat) for regions without any developed biomass supply infrastructure but with coal-fired power plants. Thus, this option takes advantage of existing energy infrastructures in the form of power plants and combined heat and power plants. Once the biomass supply infrastructure has been established, the fossil fuel plant with associated fossil-fuel infrastructure can be replaced with a biomass-only process such as a biofuel production unit in the form of a gasification or pyrolysis unit. It should be stressed that the biomass co-firing option should not be used as an excuse of maintaining the fossil fuel units (lock-in effect); instead, the option should go hand in hand with a clear plan on how to phase out the fossil fuel use in the longer run.

Co-firing biomass in existing coal-fired power plants offers the possibility of significantly increasing the share of biomass through a relatively small boiler-upgrade investment and impact on the overall efficiency compared to biomass-only plants, where alkali-related high-temperature corrosion can limit steam properties. Typically, $10 \%$ co-firing shares reduce the risk of alkali-related high-temperature corrosion (Al-Mansour and Zuwala, 2010; Cintas et al., 2018), while uncertain biomass supply can be handled by varying the share of co-feeding ratios (Berndes et al., 2010; IEA-ETSAP and IRENA Technology Brief E21, 2013). Thus, co-firing biomass in coal plants can provide a near-term biomass market (Cintas et al., 2018) that effectively reduces GHG emissions from coal-fired plants in short-term and motivates the development of biomass supply infrastructure that can later facilitate further development of advanced biofuel production technologies toward sufficiently high TRL.

\section{Current Technology Status}

In 2016, European Union had an installed coal power capacity of $164 \mathrm{GW}$, which generates $24.5 \%$ of the total electricity mix (Cintas et al., 2018). Worldwide, approximately 230 power and combined heat and power plants are in operation which apply co-firing with a significant proportion in Europe. In particular, the study of Roni et al. (2017) reports many EU countries that use biomass co-firing technologies in their power plants. For instance, Denmark has five co-combustion plants in which straw, wood chips, and wood pellets are the predominant co-firing fuels and relies heavily on importing wood pellets from external markets (Canada and Eastern Europe). Fourteen biomass cofiring plants are in Finland, whereas in Belgium there are seven co-firing plants, the initiation of which for electricity production started after the "green certificate" implementation in 2001. Thirty co-firing plants are reported in Germany, sewage sludge being used in approximately $50 \%$ of all plants. There are five co-firing power plants in Austria which in their majority use pulverized coal as primary fuel, whereas wood chips, mostly bark, are used as biomass. On the other hand, in Sweden, the biomass infrastructure is already well-developed and there is also not significant use of coal for electricity and heat production, making this steppingstone option not particularly interesting there.

\section{The Potential of Greening Coal-Fired Plants in EU}

Figure 4 shows that countries most reliant on coal are Germany, Poland, and the United Kingdom, the latter having a significant part of capacity retired or switching fuel during the last years (Europe Beyond $\mathrm{Coal}^{11}$ ). Germany and Poland alone are jointly

\footnotetext{
$\overline{{ }^{11} \mathrm{https} / / \text { beyond-coal.eu/database }}$
} 
120,000

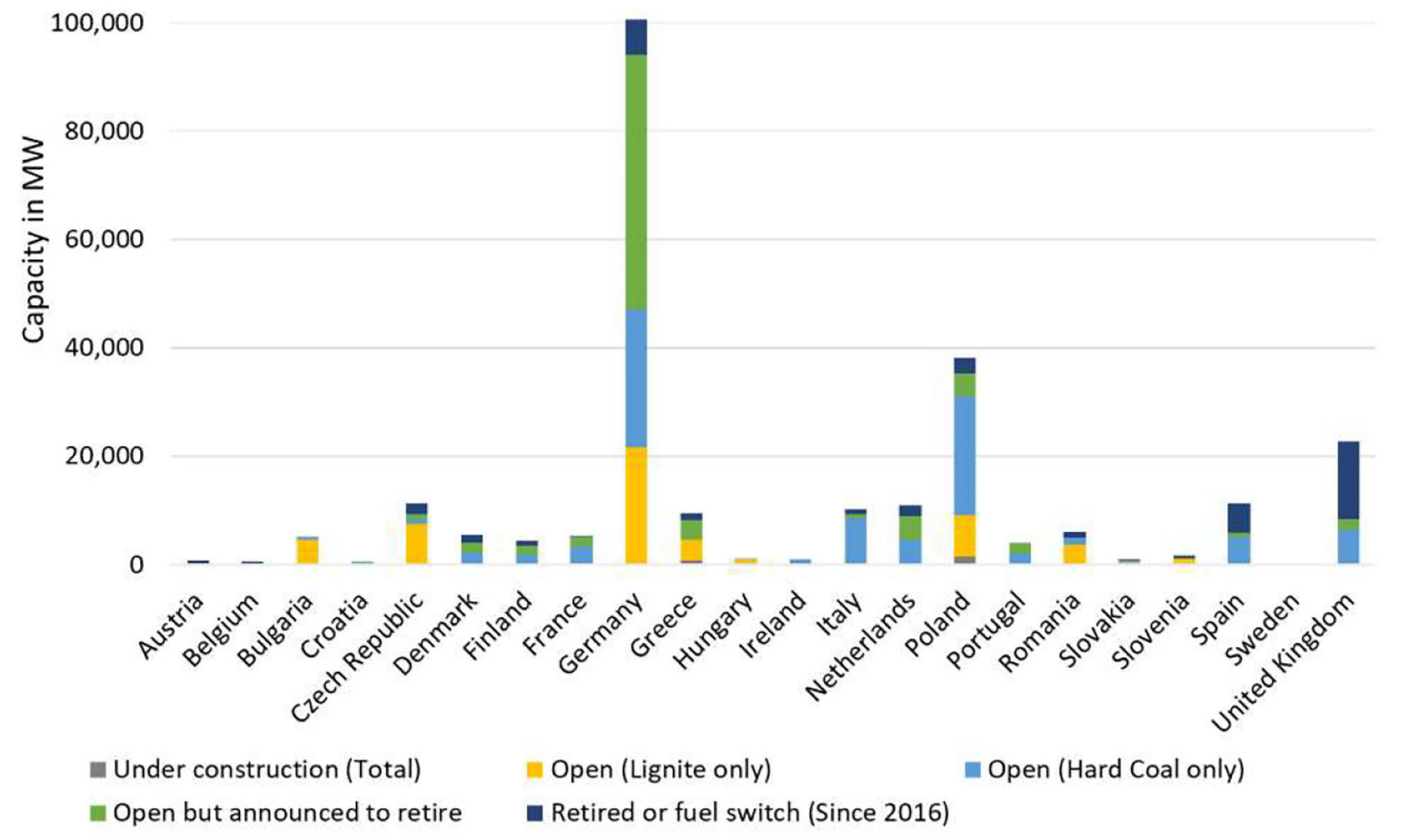

FIGURE 4 | Coal Fired plants in EU for 2019 (source: Europe Beyond Coal, https://beyond-coal.eu/database).

responsible for $51 \%$ of the EU's installed coal capacity and $54 \%$ of emissions from coal (https://climateanalytics.org/briefings/ eu-coal-phase-out/); clearly, the long history in coal mining and extensive use of coal as fuel in power generation make some countries more than others prone to "carbon lock-in" and impedes carbon phase out (Rentier et al., 2019). Countries with power plants which announced to retire or already retired most or a significant part of the coal based power generation can be considered as candidate points of developing biofuels processes making use of the phased-out infrastructures to meet the EU climate and energy targets (EU Emissions Trading System-EU ETS).

Hansson et al. (2009) assessed biomass co-firing with coal in existing coal-fired power plants in EU-27, and Bertrand et al. (2014) matched the demand for biomass-based electricity with the potential biomass supply in Europe considering scenarios for both biomass co-firing in coal plants and dedicated biomass power plants. The study of Cintas et al. (2018) provides two scenarios for potential greening of existing coal-fired plants in $\mathrm{EU}$ countries, either converting the power plants to $100 \%$ biomass-firing plants (Scenario 1) or using the sites of the power plants to establish pyrolysis units for producing a raw bio-oil to be transported to petroleum refineries (Scenario 2), which was discussed as a direct option for the production of biofuels. Scenario 1 assumes that all existing co-firing plants and the coal-fired power plants identified as suitable for co-firing will be retrofitted to allow coal to be completely substituted by biomass; the plants will only use biomass, provided it is available. This kind of transition has been seen in the United Kingdom (UK), for instance, where three coal plants were converted to biomass fired plants (Roni et al., 2017). Suitable plants in the same study are economically feasible if the plant was constructed after 1990. In Scenario 2, it is assumed that pyrolysis units are built on current coal power plant sites. All coal power plants available were assumed to represent suitable sites for bio-oil production. Then, existing refineries with hydrocrackers are assumed to shift from petroleum to bio-based oil. The capacity of each pyrolysis unit is set to $100 \mathrm{MW}$ bio-oil, corresponding to the planned size of the GoBiGas phase two project (100 MW bio-methane) (Alamia et al., 2017). In the same study, it was shown in GIS maps where residues can be collected to meet the biomass demand in each country.

The results of this analysis showed that bio-oil plants (each $100 \mathrm{MW}$ ) are built on all the existing coal power plant sites, producing 970 PJ of bio-oil and using about 1,493 PJ biomass. Results also showed that the largest bio-oil producers are 
naturally the countries with most coal power plants, namely Poland (97 units), Germany (93), the Czech Republic (43), Spain (20), Romania (17), Italy (15), and the UK.

Table 2 summarizes the options for indirect integration of biomass to liquid fuels technologies into existing fossil infrastructures, mainly contributing to the development of the logistics systems. The information is arranged in order to be clear what the current status, opportunities, and barriers for the integration of these technologies into existing fossil infrastructures are. For co-firing of coal-fired plants with biomass the basic opportunity of greening refers to the near term adaptation of specific areas in biomass supply and logistics infrastructures. Thus, this strategy prepares the ground for biofuel plants after the phasing out of fossil-fuel infrastructures. Even though this is a low-risk transition toward biomass use, a series of technical and economic factors may act as barriers in the long-term strategies for biofuel plants implementation, mainly due to lock-in effects and the lack of incentives of the energy markets toward radical changes for other renewable technologies.

Regarding the effect of DH networks, one can differentiate between regions with existing $\mathrm{DH}$ infrastructure and potential expansion plans and those with plans for new $\mathrm{DH}$ infrastructure. Those regions with existing DH networks and biomass fluidized bed boilers, thus having already biomass supply chains and consequently already having realized this steppingstone option, can be considered as drivers for other regions with only fossilbased DH networks or only DH network construction plans. This steppingstone serves the technological opportunity to convert the biomass boilers to dual fluidized gasifiers as excess heat sources, restricted of course from the uncertainty of the future evolution of the heat supply technologies and the expansion potential of the DH network in each EU country.

\section{INDIRECT OPTIONS FOR GREENING FOSSIL-FUEL INFRASTRUCTURES-OTHER INTEGRATION OPTIONS}

Co-location of biomass processing plants at existing industrial process sites offers interesting integration opportunities for heat and material flows, as well as the possibility to make use of the existing infrastructure. Some opportunities of this kind are presented here for four industrial sectors: oil, steel, pulp and paper, and 1st generation ethanol plants.

\section{Oil Refineries and Petrochemical Industry}

Based on the increasing demand of hydrogen in the oil refinery several studies refer to the production of hydrogen by biomass gasification in on-site installations of gasification units. Integrated configurations with gasification plants is investigated, for example, by Arellano Garcia et al. (2017), who analyzed the integration of biorefineries and oil refineries for the reduction of $\mathrm{CO}_{2}$ emissions. The study investigates the case of a gasification unit that is fed with pyrolysis oil, biodiesel, and refinery residue, upgrading the syngas composition with water-gas shift reaction, before proceeding to production of clean hydrogen or liquid hydrocarbon fuels via FT synthesis.

In the study of Johansson et al. (2012) the integration of different biomass gasification technologies with an oil refinery for production of hydrogen is investigated through scenarios which assess the $\mathrm{CO}_{2}$ emissions balance of the system. In the same context, Brau et al. (2013) studied the substitution of existing fossil fuel-based hydrogen production units in a refinery with a process based on indirect steam gasification of woody biomass. Furthermore, Johansson et al. (2014) investigated the integration of bio-FT fuels into a complex oil refinery, either by co-feeding the FT syncrude with crude oil in existing oil refinery facilities or by investing in new units for the FT syncrude processing and achieving heat and mass flow integration (e.g., off gases exploitation for energy sufficiency instead of natural gas).

\section{Steel Industry}

The opportunities to use biomass in iron and steel industry is to replace fossil carbon with carbon from biomass in coke making (in blends of $2-10 \%$ ), sintering (for production of bio-sinter enabling replacement ratio of coal up to $60 \%$ ), in blast furnace (partially replacement of coke from biomass as a reducing agent) or as a fuel in heating furnaces (Mousa et al., 2016). For instance, Mandova et al. (2018) developed the Global Suitability Index as an assessment methodology to identify countries which are potentially suitable for integrating biomass into their iron and steel making processes via the integrated blast furnace-basic oxygen furnace route, which provides $73 \%$ of the world's steel.

Industrial symbiosis opportunities may occur between a stand-alone biorefinery and a steel industry where excess heat from the iron and steel industry can be used in processes at the biorefinery (Sandén and Pettersson, 2013). An example can be found in the study of Ljungstedt et al. (2011), where heat and mass integration opportunities are investigated; excess heat from the steel plant can be used by an ethanol plant and the ethanol can be used as reducing agent in the blast furnace or as transportation fuel in the steel plant's vehicles. Ahlström et al. (2020) investigated the possibility to replace fossil fuels used for heating in the case of the Swedish iron and steel industry with liquefied biomethane (LBG) produced through gasification of forest residues. In this study, competition issues of LBG use were considered, such as using LBG for transportation, that influence the economic potential of LBG production.

Johansson (2013) investigated the profitability for a steel plant to produce bio-synthetic natural gas (bio-SNG) in a biomass gasifier and to substitute liquefied petroleum gas (LPG) with bio-SNG as fuel in reheating furnaces, for various energy price and carbon balance scenarios, not always ending up to profitable solutions. Lundgren et al. (2013) investigated the opportunities for methanol production from steelwork off-gases and biomass gasification in a steel plant, considering the SSAB steel plant in the town of Luleå, Sweden as a basis for the study. The results of this option, which could also be characterized as direct greening, showed that integration of methanol production in steel plants could be economically favorable and result in 
TABLE 2 | Indirect integrated options of biomass use in fossil infrastructures.

\begin{tabular}{|c|c|c|c|c|c|}
\hline Integration option & Opportunities & Barriers & Real world examples & $\begin{array}{l}\text { References/Supplementary } \\
\text { data }\end{array}$ & $\begin{array}{l}\text { Feasibility to scale up (Low, } \\
\text { Medium, High) }\end{array}$ \\
\hline $\begin{array}{l}\text { Biomass co-firing } \\
\text { with coal }\end{array}$ & $\begin{array}{l}\text { Technological } \\
\text { - Exploiting existing infrastructures as a } \\
\text { steppingstone for establishing biomass-supply } \\
\text { infrastructure where it is lacking } \\
\text { - Large number of coal-fired power plants makes } \\
\text { biomass co-firing an option in many EU countries } \\
\text { Roni et al., } 2017 \\
\text { - } 20 \% \text { co-firing (as energy content) is currently } \\
\text { applicable and more than } 50 \% \text { is technically } \\
\text { feasible, whereas a usual biomass share today is } \\
\text { below } 5 \% \text { IEA-ETSAP and IRENA Technology } \\
\text { Brief E21, } 2013 \\
\text { Economic } \\
\text { - Main factors affecting the co-firing potential are } \\
\text { the biomass price, carbon price and alkali index } \\
\text { Cutz et al., } 2019 \\
\text { - Cost of retrofitting a coal-based plant is lower } \\
\text { than a dedicated } 100 \% \text { biomass plant IEA-ETSAP } \\
\text { and IRENA Technology Brief E21, } 2013 \\
\text { Supply chain } \\
\text { - Starts up biomass supply chains, potentially } \\
\text { suitable as feedstock for } 2 \text { nd generation biofuels } \\
\text { - Uncertain biomass supplies do not jeopardize the } \\
\text { fuel supply for power plant }\end{array}$ & $\begin{array}{l}\text { Technological } \\
\text { - Risk of delaying the phase-out } \\
\text { of fossil-fuel power plants } \\
\text { - A steady growing biomass } \\
\text { demand for co-firing may be } \\
\text { considered a lock-in risk } \\
\text { Berndes et al., } 2010 \\
\text { Economic } \\
\text { - Cost of collection, handling, } \\
\text { preparation and transportation } \\
\text { of biomass, in comparison } \\
\text { with the relatively low cost of } \\
\text { coal } \\
\text { Supply chain } \\
\text { - Cost of co-firing is affected by } \\
\text { the plant location and the key } \\
\text { cost element is the biomass } \\
\text { feedstock IEA-ETSAP and } \\
\text { IRENA Technology Brief E21, } \\
2013 \\
\text { - A substantial increase in } \\
\text { biomass co-firing could } \\
\text { increase competition with } \\
\text { other biomass uses }\end{array}$ & $\begin{array}{l}\text { - Data for location and } \\
\text { capacity of coal co-fired } \\
\text { power plants in the EU } \\
\text { member states Berndes et al., } \\
2010 \\
\text { - Biomass co-firing projects } \\
\text { and costs in China and the } \\
\text { US Xu et al., } 2020 \\
\text { - Reporting of the existing } \\
\text { co-firing plants with } \\
\text { technologies and availability of } \\
\text { biomass resources in different } \\
\text { countries of the world Roni } \\
\text { et al., } 2017\end{array}$ & $\begin{array}{l}\text { Database with information } \\
\text { on coal power plants in EU } \\
\text { (Europe Beyond Coal, https:// } \\
\text { beyond-coal.eu/database/) } \\
\text { - The costs of retrofitting an } \\
\text { existing coal-fired power plant } \\
\text { for co-firing range between } \\
\text { USD300-700/kW with } \\
\text { European estimates around } \\
\text { €220/kW IEA-ETSAP and } \\
\text { IRENA Technology Brief E21, } \\
2013\end{array}$ & $\begin{array}{l}\text { Higha (with respect to the } \\
\text { preparation of the biomass } \\
\text { market and infrastructure) }\end{array}$ \\
\hline $\begin{array}{l}\text { Integration of } \mathrm{DH} \\
\text { with biofuel } \\
\text { production } \\
\text { processes based on } \\
\text { biomass gasification } \\
\text { with subsequent } \\
\text { synthesis to biofuels }\end{array}$ & $\begin{array}{l}\text { Technological } \\
\text { - Integration of biofuel plants with DH systems } \\
\text { would improve the cost-competitiveness of these } \\
\text { biofuels } \\
\text { - Potential to convert fluidized bed boilers to dual } \\
\text { fluidized gasifiers (e.g., in Sweden) } \\
\text { Economic } \\
\text { - By retrofitting an existing boiler from district } \\
\text { heating to a gasifier producing advanced biofuels } \\
\text { the cost of the investment would be reduced by } \\
10-20 \% \text { compared to a new stand-alone plant } \\
\text { Thunman et al., } 2018 \\
\text { Supply chain } \\
\text { - Starts up biomass supply chains, potentially } \\
\text { suitable as feedstock for 2nd generation biofuels }\end{array}$ & $\begin{array}{l}\text { Technological } \\
\text { - Highly dependent on the } \\
\text { competitiveness against other } \\
\text { heat supply options and in } \\
\text { particularly CHP, which is } \\
\text { dominating the DH heat supply } \\
\text { in most EU member states } \\
\text { Economic } \\
\text { - Dependence on existence of } \\
\text { financial incentives to retrofit } \\
\text { boilers into gasifiers } \\
\text { Supply chain } \\
\text { - The development of biomass } \\
\text { logistics is based on the other } \\
\text { existing competitive } \\
\text { technologies for energy supply } \\
\text { in DH systems }\end{array}$ & $\begin{array}{l}\text { - The case of Sweden's } \\
\text { GoBiGas plant in a region with } \\
\text { an established DH network } \\
\text { Thunman et al., } 2018\end{array}$ & $\begin{array}{l}\text { - Data for DH supply } \\
\text { technologies and respective } \\
\text { fuels used, for selected EU } \\
\text { countries for } 2012 \text { (EC, 2016) } \\
\text { - DH share in final heating } \\
\text { demand for space heating and } \\
\text { data on DH profiles in EU } \\
\text { countries Mathiesen et al., } \\
2019\end{array}$ & $\begin{array}{l}\text { High }^{\mathrm{a}} \text { (with respect to the } \\
\text { preparation of the biomass } \\
\text { market and infrastructure) }\end{array}$ \\
\hline
\end{tabular}

${ }^{a} A$ near-term option to displace fossil fuels and pave the way for $2^{\text {nd }}$ generation biofuels. 
$\mathrm{CO}_{2}$ emissions reductions and improvement of the overall plant energy efficiency.

\section{Pulp and Paper and Saw-Mills}

Synergies among pulp and paper industry and biorefineries mainly take advantage of the fact that both type of facilities use biomass resources and, thus, can exploit an existing mature infrastructure and know-how for handling large volumes of biomass. Other opportunities refer to access of heat integration practices. Sandén and Pettersson (2013) provided an overview of opportunities for developing biofuels production in the pulp and paper industry, including the extraction of hemicelluloses prior to pulping for upgrading toward fuels and chemicals, lignin extraction from black liquor for heating purposes replacing fossil fuels or upgrading, black liquor gasification for production of biofuels or electricity generation, and conversion of an existing pulp mill or one of the fiber lines to an ethanol production plant through cellulose extraction before pulping. Mongkhonsiri et al. (2018) also investigated possible pathways for a biorefinery integration with an existing pulp mill toward production of biofuels and value-added chemicals.

Saw-mills can be integrated with bio-SNG production according to the studies of Ahlström et al. (2017) and Zetterholm et al. (2020). Liquified Biogas (LBG) production is an effective way for a saw-mill to utilize its by-products and the policy and financial support were assessed in order to facilitate largescale investments and maintain high production levels in sawmill integrated production of LBG. Isaksson et al. (2012) and Tunå et al. (2012) investigated energy integration schemes among gasification plants and pulp and paper plants and assessed $\mathrm{CO}_{2}$ emissions. The former study was based on the integration among three possible biomass gasification-based energy mills with an existing thermo-mechanical pulp (TMP) mill, co-located with a saw-mill producing electricity, methanol or FT liquids. The latter study assessed various gasification technologies with a possible portfolio of products (e.g., methanol, DME, FT fuels). The study of Jafri et al. (2020) presents a techno-economic and GHG emissions performance of five drop-in biofuel pathways based on black liquor lignin separation with hydrotreatment (i.e., where lignin and VGO mixture can be conveyed to the refinery and coprocessed with crude oil derivatives) or black liquor gasification with catalytic synthesis (i.e., via syngas upgrading to "stabilized" methanol and then methanol to gasoline synthesis at a petroleum refinery). However, lignin separation pathways lower the entire TRL ranging between 4 and 6 , making these configurations out of scope for the current study. Moreover, technologies facilitating the mixing of the final product fuel with the corresponding oil refinery fuel (e.g., methanol to gasoline such as in the case of black liquor gasification-catalytic synthesis route and mixing the gasoline with the oil refinery one) are also outside the scope of this study, as mentioned in the boundaries of the framework for this analysis.

\section{Integration of 1st and 2nd Generation Bioethanol Plants}

Several 2nd generation biofuel facilities (e.g., in Brazil, Finland, US) are already co-located with 1st generation biofuel production facilities. Moreover, an increasing number of US 1st generation biofuel companies are exploring how to retrofit their processes to incorporate cellulosic feedstocks into their production lines (IEARETD, 2016). Various studies have focused on the integration of 1st and 2nd generation of biofuels, either based on material and equipment integration or heat integration. For instance, the study of Lennartsson et al. (2014) investigated the integration of a 2 nd generation ethanol (lignocellulosic) into 1st generation ethanol at the fermentation stage and the fungal cultivation stage. Other studies focused on the development of alternative configurations schemes in the form of process flowsheets (Dias et al., 2012) or heat integration showing that the heating and cooling energy demands could be reduced to a great extent (Joelsson et al., 2014). These studies demonstrate the benefits of sharing the existing infrastructures, logistics, and utilities.

Table 3 summarizes the indirect options for BTL fuels technologies into various existing process industries. The options are characterized with respect to opportunities and barriers for integration together with real world examples with some references. The opportunities refer to the development of biofuels plants close to industrial facilities, including non-fossil industry. The benefit arises from mass and energy integration between the advanced biofuel plant and the corresponding industrial infrastructure, including non-carbon mass integration through hydrogen production from biomass or heat integration with biomass being used for heating needs. Additionally, this colocation of advanced biofuel plants with potential retrofitting of existing facilities is benefited from utilities infrastructures in a total site analysis perspective, sharing of experienced personnel, and market penetration in already known market conditions (e.g., for 1st and 2nd generation ethanol plants). Challenges may be connected to the technical barriers of using biomass but also to bringing a totally new material (i.e., biomass) to industrial sites, such as the case of biomass and coal coke mixing in steel industry. Other techno-economical barriers refer to the low efficiency of 2 nd generation ethanol plants and the lower TRL of lignin utilization toward a wider product portfolio.

\section{CONCLUSIONS}

To ramp up biofuels production processes and be part of a longterm climate strategy requires incentives and the overcoming of technological barriers. Although strongly decreasing the dependence on fossil-based resources is an indispensable part of climate strategies, in short- to mid-term using existing fossil-fuel infrastructures to incorporate the use of biomass is a low-risk option. Greening of fossil fuels infrastructures to enhance the deployment of liquid biofuels production is in line with the action plans of European Green Deal and the Sustainable Development Goals (e.g., SDG7-Affordable \& Clean Energy, SDG 8-Decent work and economic growth, and SDG9-Industry, Innovation, and Infrastructure). However, avoiding lock-in effects should also be part of any proposed solution for greening fossilbased infrastructures.

The development of the thermochemical biomass conversion technologies to produce liquid fuels is currently lacking 
TABLE 3 | Indirect integrated options of biomass use in processing industries.

\begin{tabular}{|c|c|c|c|c|c|}
\hline Integration option & Opportunities & Barriers & Real world examples & $\begin{array}{l}\text { References/Supplementary } \\
\text { Data }\end{array}$ & $\begin{array}{l}\text { Feasibility to scale } \\
\text { up (Low, Medium, } \\
\text { High) }\end{array}$ \\
\hline $\begin{array}{l}\text { Biomass use in } \\
\text { industrial plants }\end{array}$ & $\begin{array}{l}\text { Technological } \\
\text { - Exploiting existing } \\
\text { infrastructures as a } \\
\text { steppingstone for establishing } \\
\text { biomass-supply infrastructure } \\
\text { where such is lacking } \\
\text { - Lignocellulosic ethanol is on } \\
\text { the verge of being commercial } \\
\text { exploiting integration in early } \\
\text { operations with 1st generation } \\
\text { plants } \\
\text { - Black liquor production is part } \\
\text { of a pulp and paper industry } \\
\text { facilitating exploitation routes } \\
\text { close to commercialization } \\
\text { such as gasification } \\
\text { Economic } \\
\text { - Potential heating and cooling } \\
\text { demand reduction through } \\
\text { heat integration } \\
\text { - Share of existing } \\
\text { infrastructures and no-need of } \\
\text { investments anew } \\
\text { Supply chain } \\
\text { - Starts up biomass supply } \\
\text { chains, potentially suitable as } \\
\text { feedstock for advanced } \\
\text { biofuels }\end{array}$ & $\begin{array}{l}\text { Technological } \\
\text { - The production of bio-coke (coal and biomass blend) } \\
\text { with desired physical and chemical properties is still } \\
\text { challenging Mousa et al., } 2016 \\
\text { - Constraints of the development of 2nd generation } \\
\text { ethanol Lennartsson et al., 2014: } \\
\text { - Need for relatively severe pretreatments of the } \\
\text { feedstock due to recalcitrance of biomass inhibiting } \\
\text { fermentation } \\
\text { - Production of cost competitive enzymes to hydrolyze } \\
\text { the cellulose } \\
\text { - Relatively low concentrations which increase the cost } \\
\text { of distillation and wastewater treatment } \\
\text { - Some exploitation steps in pulp and paper are of low } \\
\text { TRL e.g., lignin separation and hydrotreatment } \\
\text { restricting the options of integration with other } \\
\text { industries e.g., oil refineries } \\
\text { Economic } \\
\text { - Economic assessment of integrations does not give } \\
\text { always profitable results, e.g., the case of } \\
\text { bio-synthetic gas in a biomass gasifier to substitute } \\
\text { LPG for a steel plant (Johansson, } 2013 \text { ) and scenarios } \\
\text { of various biorefinery concepts for an existing pulp and } \\
\text { paper process Mongkhonsiri et al., 2018 } \\
\text { - Scales of liquid biofuel plants are constrained and } \\
\text { highly dependent on the capacity of the main industrial } \\
\text { facility. This affects also the economic profitability of } \\
\text { the new investment } \\
\text { Supply chain } \\
\text { - Competition with other uses of biomass and } \\
\text { development of alternative fuels for the transportation } \\
\text { and power sector will play an important role } \\
\text { - Possible disadvantages of co-location of } \\
\text { bio-processes with the pulping industry could be long } \\
\text { distances among plants, lack of knowledge about the } \\
\text { products and markets, and limited possibilities to } \\
\text { deliver low-temperature excess heat to DH networks } \\
\text { Sandén and Pettersson, } 2013\end{array}$ & $\begin{array}{l}\text { - The status of lignocellulosic ethanol } \\
\text { plants in EU can be found in the } \\
\text { report of IEA Bioenergy Report } \\
\text { (2020) } \\
\text { - Two reported facilities producing } \\
\text { bioethanol from cellulose via the } \\
\text { biochemical route are the plant in } \\
\text { Crescentino, Italy, constructed by } \\
\text { Beta Renewables, and the plant } \\
\text { Kajaani/St1 in Finland, by Cellunolix } \\
\text { technology }\end{array}$ & $\begin{array}{l}\text { - Data for pilot, demonstration } \\
\text { and commercial plants with } \\
\text { references on synergies with } \\
\text { industrial sectors can be found } \\
\text { in Landälv et al. (2017a,b) and } \\
\text { IEA Bioenergy Report (2020) } \\
\text { - Overview of the European } \\
\text { steel industry, including crude } \\
\text { steel production capacity per } \\
\text { EU country for } 2019 \\
\text { EUROFER, } 2020 \\
\text { - Data for total pulp production, } \\
\text { and paper and board } \\
\text { production per EU country for } \\
2019 \text { CEPI, } 2020\end{array}$ & $\begin{array}{l}\text { Medium to Higha (with } \\
\text { respect to the } \\
\text { preparation of the } \\
\text { biomass market and } \\
\text { infrastructure) }\end{array}$ \\
\hline
\end{tabular}

${ }^{a} A$ near-term option to displace fossil fuels and pave the way for 2nd generation biofuels. 
the experience of operating at large scale, namely at commercially relevant capacities for liquid biofuels. For instance, BTL production is mainly constrained by the biomass gasification technology and the catalytic upgrading technologies of the biomass pyrolysis oil, respectively. Integrating these technologies within oil-refineries provides mixing opportunities of intermediates, exploiting at the same time logistics infrastructure and engineering knowhow and may significantly reduce the capital investment risk compared to stand alone biofuel plants. However, technological barriers still exist, mainly with respect to bio-oil quality for co-processing with refinery gas-oils and large-scale operation and syngas cleaning for the biomass gasification option. The biomass feedstock variability can be more easily handled when biomass conversion technologies are integrated into fossil infrastructures, however the cost of the biomass feedstock will still require dedicated support policies to reduce production costs.

Geographical aspects are also of importance with respect to available capacities, feedstock availability and supply chain constraints. Clearly, not all greening solutions are relevant or efficient for different regions. EU has significant FCC capacities in oil refineries for co-processing bio-oil but not so many FT synthesis plants which could provide additional options for integrating BTL processes. On the other hand, the overall system efficiency can be increased by exploiting excess heat from gasification plants to $\mathrm{DH}$ systems in $\mathrm{EU}$, which represent a large heat sink. Thus, extending the use of biomass boilers in existing, under construction or planned $\mathrm{DH}$ systems can together with co-firing of biomass in coal-fired power plants prepare the conditions for regions where biomass infrastructure is missing.

\section{REFERENCES}

ADVANCEFUEL (2020a). Key Needs for Development and Potential for Innovations for Highly Efficient and Low Risk Biomass Conversion Technologies, Including Required Financial Instruments. Available online at: http://www. advancefuel.eu/contents/reports/d33-potential-for-innovations-for-biomassconversion-technologies.pdf

ADVANCEFUEL (2020b). Socio-Economic Assessment Total System Costs of RESfuel Scenarios and the Employment Impacts of Biofuel Production. Available online at: http://www.advancefuel.eu/contents/reports/d63-socioeconomicanalysis-final.pdf (accessed February 27, 2021)

Agblevor, F. A., Mante, O., McClung, R., and Oyama, S. T. (2012). Co-processing of standard gas oil and biocrude oil to hydrocarbon fuels. Biomass Bioenergy 45, 130-137. doi: 10.1016/j.biombioe.2012. 05.024

Ahlström, J., Zetterholm, J., Pettersson, K., Harvey, S., and Wetterlund, E. (2020). Economic potential for substitution of fossil fuels with liquefied biomethane in Swedish iron and steel industry - synergy and competition with other sectors. Energy Conver. Manage. 209:112641. doi: 10.1016/j.enconman.2020.112641

Ahlström, J. M., Pettersson, K., Wetterlund, E., and Harvey, S. (2017). Value chains for integrated production of liquefied bio-SNG at sawmill sites - technoeconomic and carbon footprint evaluation. Appl. Energy 206, 1590-1608. doi: 10.1016/j.apenergy.2017.09.104

Air Resources Board (2017). Co-processing of Biogenic Feedstocks in Petroleum Refineries. Available online at: https://ww2.arb.ca.gov/sites/default/files/ classic//fuels/lcfs/lcfs_meetings/020717_staffdiscussionpaper.pdf
It is important to note that greening fossil infrastructures should still be viewed as part of a more long-term strategy targeting at phasing out the fossil-fuel infrastructure and needs financial and legislative incentives to facilitate further technological improvement. Thus, the policy dimension, regional or international, should be incorporated for further analysis of the greening options. This includes identification of policy mechanisms and proper funding for innovation across the advanced biofuels value chain, including the potential of using fossil infrastructures. Such an analysis could identify current shortcomings in existing policies toward a more stable and efficient policy framework for the transportation sector and provide a clear direction for increasing investor confidence and successful market uptake.

\section{AUTHOR CONTRIBUTIONS}

PK performed the literature search, contributed to the organization of the material, contributed to the critical discussion of the findings, and to the final edition of the manuscript. FJ contributed to the critical discussion of the findings. SP contributed to the organization of the material, and to the critical discussion of the findings and the final edition of the findings. All authors contributed to the article and approved the submitted version.

\section{ACKNOWLEDGMENTS}

The authors would like to acknowledge financial support from the European Union's Horizon 2020 research and innovation programme under grant agreement $\mathrm{N}^{\circ} 764799$.

Alamia, A., Larsson, A., Breitholtz, C., and Thunman, H. (2017). Performance of large-scale biomass gasifiers in a biorefinery, a state-of-the-art reference. Int. J. Energy Res. 41, 2001-2019. doi: 10.1002/er.3758

Ali, A. M. A., Mustafa, A., and Yassin, K. E. (2018). A techno-economic evaluation of bio-oil co- processing within a petroleum refinery. Biofuels. doi: 10.1080/17597269.2018.1519758

Al-Mansour, F., and Zuwala, J. (2010). An evaluation of biomass co-firing in Europe. Biomass Bioenergy 34, 620-629. doi: 10.1016/j.biombioe.2010.01.004

Arellano Garcia, H., Ketabchi, E., and Reina, T. (2017). "Integration of biorefinery concepts in oil refineries," in Proceedings of the 27th European Symposium on Computer Aided Process Engineering - ESCAPE 27 (Barcelona).

Atashbar, N. Z., Labadie, N., and Prins, C. (2016). Modeling and optimization of biomass supply chains: a review and a critical look. IFAC PapersOnLine 49, 604-615. doi: 10.1016/j.ifacol.2016.07.742

Awudu, A., and Zhang, J. (2012). Uncertainties and sustainability concepts in biofuel supply chain management: a review. Renew. Sustain. Energy Rev. 16, 1359-1368. doi: 10.1016/j.rser.2011.10.016

Barthe, P., Chaugny, M., Roudier, S., and Sancho, L. D. (2015). Best Available Techniques (BAT) Reference Document for the Refining of Mineral Oil and Gas. Seville: European Commission.

Beims, R., Bertoli, S., Botton, V., Ender, L., Simionatto, E., Meier, et al. (2017). Co-processing of thermal cracking bio-oil at petroleum refineries. Brazilian J. Petrol. Gas 11, 99-113. doi: 10.5419/bjpg2017-0009

Berndes, G., Hansson, J., Egeskog, A., and Johnsson, F. (2010). Strategies for 2nd generation biofuels in EU - co-firing to stimulate feedstock supply development and process integration to improve energy 
efficiency and economic competitiveness. Biomass Bioenergy 34, 227-236. doi: 10.1016/j.biombioe.2009.07.007

Berndes, G., Hansson, J., Egeskog, A., and Werner, S. (2008). Bioenergy Expansion Strategies for Europe. Cost Effective Biomass Allocation and Biofuel Steppingstones. REFUEL WP5 Final Report. Available online at: https:// ec.europa.eu/energy/intelligent/projects/sites/iee-projects/files/projects/ documents/refuel_bieoenergy_expansion_strategy_for_europe.pdf

Bertrand, V., Dequiedt, B., and Le Cadre, E. (2014). Biomass for electricity in the EU-27: potential demand, $\mathrm{CO}_{2}$ abatements and break even prices for co-firing. Energy Policy 73, 631-644. doi: 10.1016/j.enpol.2014.06.007

Bhatt, A. H., Zhang, Y., and Heath, G. (2020). Bio-oil co-processing can substantially contribute to renewable fuel production potential and meet air quality standards. Appl. Energy 268:114937. doi: 10.1016/j.apenergy.2020.114937

Biofuels Barometer (2017). Available online at: https://www.eurobserv-er.org/ biofuels-barometer-2017

Brar, J. S., Singh, K., Wang, J., and Kumar, S. (2012). Cogasification of coal and biomass: a review. Int. J. Forest. Res. 2012:363058. doi: 10.1155/2012/363058

Brau, J. F., Morandin, M., and Berntsson, T. (2013). Hydrogen for oil refining via biomass indirect steam gasification: energy and environmental targets. Clean Technol. Environ. Policy 15, 501-512. doi: 10.1007/s10098-013-0591-9

Bunting, B., Bunce, M., Barone, T., and Storey, J. (2010). Fungible and Compatible Biofuels: Literature Search, Summary, and Recommendations. Oak Ridge, TN: Oak Ridge National Laboratory, Fuels, Engines, and Emissions Research Center. Available online at: https://www.energy.gov/sites/prod/files/2014/03/ f14/20110512135206-0.pdf

Canabarro, N., Soares, J. F., Anchieta, C. G., Kelling, C. S., and Mazutti, M. A. (2013). Thermochemical processes for biofuels production from biomass. Sustain. Chem. Proc. 1:22. doi: 10.1186/2043-7129-1-22

CEPI (2020). Key Statistics 2019 European Pulp and Paper Industry. Available online at: https://www.cepi.org/wp-content/uploads/2020/07/Final-KeyStatistics-2019.pdf

Cintas, O., Berndes, G., Englund, O., Cutz, L., and Johnsson, F. (2018). Geospatial supply-demand modeling of biomass residues for co- firing in European coal power plants. Bioenergy 10, 786-803. doi: 10.1111/gcbb.12532

Concawe Report (2020). Concawe Review 29. Available online at: https://www. concawe.eu/wp-content/uploads/Concawe-Review-29-1-web-resolutionPDF.pdf

Cutz, L., Berndes, G., and Johnsson, F. (2019). A techno-economic assessment of biomass co-firing in Czech Republic, France, Germany and Poland. Biofuels Bioprod. Biorefin. 13, 1289-1305. doi: 10.1002/bbb.2034

de Jong, E., and Jungmeier, G. (2015). "Chapter 1: Biorefinery concepts in comparison to petrochemical refineries in industrial biorefineries and white biotechnology," in Industrial Biorefineries and White Biotechnology, eds A. Pandey, R. Höfer, C. Larroche, M. Taherzadeh, and M. Nampoothiri (Amsterdam; Oxford: Elsevier), 3-33. doi: 10.1016/B978-0-444-63453-5.00001-X

Dias, M. O. S., Junqueira, T. L., Jesus, C. D. F., Rossell, C. E. V., Maciel Filho, R., and Bonomi, A. (2012). Improving second generation ethanol production through optimization of first generation production process from sugarcane. Energy 43 , 246-252. doi: 10.1016/j.energy.2012.04.034

Dimitriou, I., Goldingay, H., and Bridgwater, A. (2018). Techno-economic and uncertainty analysis of biomass to liquid (BTL) systems for transport fuel production. Renew. Sustain. Energy Rev. 88, 160-175. doi: 10.1016/j.rser.2018.02.023

Directorate-General for Mobility and Transport (2018). Building Up the Future, Cost of Biofuel. Luxembourg: EU Publications.

DOE/EERE (2013). Replacing the Whole Barrel: To Reduce U.S. Dependence on Oil. U.S. Department of Energy, Office of Energy Efficiency \& Renewable Energy. Available online at: https://wwwl.eere.energy.gov/bioenergy/pdfs/replacing barrel_overview.pdf

Doliente, S., and Samsatli, S. (2020). Integrated production of fuels, energy and chemicals from Jatropha Curcas: multiobjective optimisation of sustainable value chains. Chem. Eng. Trans. 80, 343-348. doi: 10.3303/CET2080058

Doug, B. (2006). European Market Study for Bio Oil (Pyrolysis Oil). Ottawa, ON: Climate Change Solutions National Team Leader- IEA Bioenergy Task 40- Bio-trade. Available online at: http://www.unecefaoiufro.lsu.edu/biofuels/ documents/2007July/SRN_009.pdf
Elia, J. A., Baliban, R. C., Xiao, X., and Floudas, C. A. (2011). Optimal energy supply network determination and life cycle analysis for hybrid coal, biomass, and natural gas to liquid (CBGTL) plants using carbon-based hydrogen production. Comput. Chem. Eng. 35, 1399-1430. doi: 10.1016/j.compchemeng.2011.01.019

ETIP Bioenergy (2020). ETIP Bioenergy Working Group 2 - Conversion Processes and ETIP-B-SABS2 Project Team (2020) Current Status of Advanced Biofuels Demonstrations in Europe. Available online at: https:// www.etipbioenergy.eu/images/ETIP-B-SABS2_WG2_Current_Status_of_ Adv_Biofuels_Demonstrations_in_Europe_Mar2020_final.pdf

EUROFER (2020). European Steel in Figures 2020. Available online at: https:// www.eurofer.eu/publications/brochures-booklets-and-factsheets/europeansteel-in-figures-2020/

European Commission (2016a). COM, An EU Strategy on Heating and Cooling. https://ec.europa.eu/energy/sites/ener/files/documents/1_EN_ACT_ part1_v14.pdf

European Commission (2016b). Mapping and Analyses of the Current and Future (2020-2030) heat-ing/cooling fuel deployment (fossil/renewables), Final Report. Available online at: https://ec.europa.eu/energy/studies/mapping-andanalyses-current-and-future-2020-2030-heatingcooling-fuel-deployment_en

European Commission (2016c). Sectoral Fitness Check for the Petroleum Refining Sector. Commission Staff Working Document, Brussels. Available online at: https://ec.europa.eu/energy/sites/ener/files/documents/SWD_2015_ 284_F2_STAFF_WORKING_PAPER_EN_V4_P1_835479.pdf

European Commission (2018). In-Depth Analysis in Support of the COM(2018): A Clean Planet for all - A European Strategic Long-Term Vision for a Prosperous, Modern, Competitive and Climate Neutral Economy. Available online at: https://knowledge4policy.ec.europa.eu/publication/depth-analysis-supportcom2018-773-clean-planet-all-european-strategic-long-term-vision_en

Fogassy, G., Thegarid, N., Toussaint, G., van Veen, A. C., Schuurman, Y., and Mirodatos, C. (2010). Biomass derived feedstock co-processing with vacuum gas oil for second-generation fuel production in FCC units. Appl. Catal. B Environ. 96, 476-485. doi: 10.1016/j.apcatb.2010.03.008

Freeman, C. J., Jones, S. B., Padmaperuma, A. B., Santosa, M., Valkenburg, C., and Shinn, J. (2013). Initial Assessment of US Refineries for Purposes of Potential BioBased Oil Insertions. U.S. Department of Energy. Available online at: https:// www.pnnl.gov/main/publications/external/technical_reports/PNNL-22432. pdf

Fuels Europe (2018). Vision 2050: A Pathway for the Evolution of the Refining Industry and Liquid Fuels. Available online at: https://www.fuelseurope.eu/wpcontent/uploads/DEF_2018_V2050_Narratives_EN_digital.pdf

Gollakota, A. R., Reddy, M., Subramanyam, M. D., and Kishore, N. (2016). A review on the upgradation techniques of pyrolysis oil. Renew. Sustain. Energy Rev. 58, 1543-1568. doi: 10.1016/j.rser.2015.12.180

Gudde, N., Larivé, J., and Yugo, M. (2019). Refinery 2050: Conceptual Assessment. Brussels, Concawe: Concawe Special Task Force Refinery 2050.

Hannula, I., and Kurkela, E. (2013). Liquid Transportation Fuels via Large-Scale Fluidised-Bed Gasification of Lignocellulosic Biomass. VTT Technical Research Center of Finland. Available online at: https://www.vtt.fi/inf/pdf/technology/ 2013/T91.pdf

Hansson, J., Berndes, G., Johnsson, F., and KJärsrtad, J. (2009). Co-firing biomass with coal for electricity generation - an assessment of the potential in EU27. Energy Policy 37, 1444-1455. doi: 10.1016/j.enpol.2008.12.007

Hileman, J. I., Ortiz, D. S., Bartis, J. T., Wong, H. M., Donohoo, P. E., Weiss, M. A., et al. (2009). Near-Term Feasibility of Alternative Jet fuels. Technical report, RAND Infrastructure, Safety and Environment. Available online at: https:// www.rand.org/pubs/technical_reports/TR554.html

Hu, J., and Lu, Y. (2012). Application of Fischer-Tropsch synthesis in biomass to liquid conversion. Catalysts 2, 303-326. doi: 10.3390/catal20 20303

IEA Bioenergy Report (2020). Advanced Biofuels - Potential for Cost Reduction. Available online at: https://www.ieabioenergy.com/blog/publications/newpublication-advanced-biofuels-potential-for-cost-reduction/

IEA-ETSAP and IRENA Technology Brief E21 (2013). Biomass Co-firing Technology Brief. Available online at: https://irena.org/-/media/Files/IRENA/ Agency/Publication/2013/IRENA-ETSAP-Tech-Brief-E21-Biomass-Cofiring.pdf

IEA-RETD (2016). Towards Advanced Biofuels - Options for Integrating Conventional and Advanced Biofuel Production Sites (RES-T-BIOPLANT). 
Available online at: http://iea-retd.org/wp-content/uploads/2016/08/ 20160202-IEA-RETD-RES-T-BIOPLANT-1.pdf

IRENA (2016). Innovation Outlook - Advanced Liquid Bioguels. Available online at: https:/www.irena.org/-/media/Files/IRENA/Agency/Publication/ 2016/IRENA_Innovation_Outlook_Advanced_Liquid_Biofuels_2016.pdf

Isaksson, J., Pettersson, K., Mahmoudkhani, M., Asblad, A., and Berntsson, T. (2012). Integration of biomass gasification with a Scandinavian mechanical pulp and paper mill - consequences for mass and energy balances and global $\mathrm{CO}_{2}$ emissions. Energy 44, 420-428. doi: 10.1016/j.energy.2012.06.013

Jafri, Y., Wetterlund, E., Mesfun, S., Rådberg, H., Mossberg, J., Hulteberg, C., et al. (2020). Combining expansion in pulp capacity with production of sustainable biofuels - techno-economic and greenhouse gas emissions assessment of drop-in fuels from black liquor part-streams. Appl. Energy 279:115879. doi: 10.1016/j.apenergy.2020.115879

Joelsson, E., Galbe, M., and Wallberg, O. (2014). Heat integration pf combined 1st and 2nd generation ethanol production from wheat kernels and wheat straw. Sustain. Chem. Process. 2:20. doi: 10.1186/s40508-014-0020-3

Johansson, D., Berntsson, T., and Franck, P.-Å. (2014). Integration of FischerTropsch fuel production with a complex oil refinery. Int. J. Environ. Sustain. Dev. 13, 50-73. doi: 10.1504/IJESD.2014.056413

Johansson, D., Franck, P.-Å., and Berntsson, T. (2012). Hydrogen production from biomass gasification in the oil refining industry - a system analysis. Energy 38, 212-227. doi: 10.1016/j.energy.2011.12.011

Johansson, M. T. (2013). Bio-synthetic natural gas as fuel in steel industry reheating furnaces - a case study of economic performance and effects on global $\mathrm{CO}_{2}$ emissions. Energy 57, 699-708. doi: 10.1016/j.energy.2013.06.010

Jones, S., Valkenburg, C., Walton, C., Elliott, D., Holladay, J., Stevens, D., et al. (2009). Production of Gasoline and Diesel from Biomass via Fast Pyrolysis, Hydrotreating and Hydrocracking: A Design Case. Washington, DC: Pacific Northwest National Laboratory. doi: 10.2172/950728

Kamble, A. D., Saxena, V. K., Chavan, P. K., and Mendhe, V. A. (2019). Cogasification of coal and biomass an emerging clean technology: status and prospects of development in Indian context. In. J. Min. Sci. Technol. 2, 171-186. doi: 10.1016/j.ijmst.2018.03.011

Karatzos, S., McMillan, J. D., and Saddler, J. N. (2014). The Potential and Challenges of Drop-in Biofuels. A Report by IEA Bioenergy Task 39. Available online at: http://task39.sites.olt.ubc.ca/files/2014/01/Task-39-Dropin-Biofuels-Report-FINAL-2-Oct-2014-ecopy.pdf

Karka, P., Papadokonstantakis, S., and Kokossis, A. (2017). Cradle-to-gate assessment of environmental impacts for a broad set of biomassto-product process chains. Int. J. Life Cycle Assess. 22, 1418-1440. doi: 10.1007/s11367-017-1262-6

Kumar, A., Adamopoulos, S., Jones, D., and Amiandamhen, S. O. (2021). Forest biomass availability and utilization potential in Sweden: a review. Waste Biomass Valor. 12, 65-80. doi: 10.1007/s12649-020-00947-0

Lainez-Aguirre, J. M., Pérez-Fortes, M., and Puigjaner, L. (2015). Strategic planning of biomass supply chain networks for co-combustion plants. Comput. Aid. Chem. Eng. 36, 453-474 doi: 10.1016/B978-0-444-63472-6.00018-5

Landälv, I., Maniatis, K., Waldheim, L., van den Heuvel, E., and Kalligeros, S. (2017a). Building up the Future - Cost of Biofuel. European Commission. Sub-Group on Advanced Biofuels. Sustainable Transport Forum.

Landälv, I., Maniatis, K., Waldheim, L., van den Heuvel, E., and Kalligeros, S. (2017b). Building up the Future - Technology Status and Reliability of the Value Chain. European Commission. Sub-Group on Advanced Biofuels. Sustainable Transport Forum.

Lee, J. W. (2013). Advanced Biofuels and Bioproducts. New York, NY: Springer. doi: 10.1007/978-1-4614-3348-4

Lehto, J., Oasmaa, A., Solantausta, Y., Kytö, M., and Chiaramonti, C. (2013). Fuel Oil Quality and Combustion of Fast Pyrolysis Bio-Oils. VTT Technical Research Centre of Finland. Available online at: https://www.vttresearch.com/ sites/default/files/pdf/technology/2013/T87.pdf

Lennartsson, P. R., Erlandsson, P., and Taherzadeh, M. J. (2014). Integration of the first and second generation bioethanol processes and the importance of by-products. Bioresour. Technol. 165, 3-8. doi: 10.1016/j.biortech.2014.01.127

Ljungstedt, H., Johansson, D., Johansson, M. T., and Karltorp, K. (2011). “Options for increased use and refining of biomass - the case of energy-intensive industry in Sweden," in Proceedings of World Renewable Energy Congress (Linköping). doi: $10.3384 /$ ecp 1105717
Lundgren, J., Ekbom, T., Hulteberg, C., Larsson, M., Grip, C. E., Nilsson, L., et al. (2013). Methanol production from steel-work off-gases and biomass based synthesis gas. Appl. Energy 112, 431-439. doi: 10.1016/j.apenergy.2013. 03.010

Luque, R., de la Osa, A., Campelo, J., Romero, A., Valverde, J., and Sanchez, P. (2012). Design and development of catalysts for biomass-to-liquid FischerTropsch (BTL-FT) processes for biofuels production. Energy Environ. Sci. 5, 5186-5202. doi: 10.1039/C1EE02238E

Mandova, H., Gale, W. F., Williams, A., Heyes, A. L., Hodgson, P., and Miah, K. H. (2018). Global assessment of biomass suitability for ironmaking - opportunities for co-location of sustainable biomass, iron and steel production and supportive policies. Sustain. Energy Technol. Assess. 27, 23-39. doi: $10.1016 /$ j.seta.2018.03.001

Mathiesen, B. V., Bertelsen, N., Schneider, N. C. A., García, L. S., Paardekooper, S., Thellufsen, J. Z., et al. (2019). Towards a Decarbonised Heating and Cooling Sector in Europe: Unlocking the Potential of Energy Efficiency and District Energy. Aalborg Universitet. Available online at: https://vbn.aau.dk/ ws/portalfiles/portal/316535596/Towards_a_decarbonised_H_C_sector_in_ EU_Final_Report.pdf

Melero, J., Iglesias, J., and Garcia, A. (2012). Biomass as renewable feedstock in standard refinery units. Feasibility, opportunities and challenges. Energy Environ. Sci. 5, 7393-7420. doi: 10.1039/c2ee21231e

Mongkhonsiri, G., Gani, R., Malakul, P., and Assabumrungrata, S. (2018). Integration of the biorefinery concept for the development of sustainable processes for pulp and paper industry. Comput. Chem. Eng. 119, 70-84. doi: 10.1016/j.compchemeng.2018.07.019

Mousa, E., Wang, C., Riesbeck, J., and Mikael Larsson, M. (2016). Biomass applications in iron and steel industry: an overview of challenges and opportunities. Renew. Sustain. Energy Rev. 65, 1247-1266. doi: 10.1016/j.rser.2016.07.061

Nanda, S., Mohammad, J., Reddy, S. N., Kozinski, J. A., and Dalai, A. K. (2014). Pathways of lignocellulosic biomass conversion to renewable fuels. Biomass Convers. Biorefin. 4, 157-191. doi: 10.1007/s13399-013-0097-z

Neste (2020). Neste Renewable Diesel Handbook. Espoo: Neste. Available online at: https://www.neste.com/sites/default/files/attachments/neste_renewable_ diesel_handbook.pdf

Nivard, M., and Kreijkes, M. (2017). The European Refining Sector: A Diversity of Markets? Clingendael International Energy Programme (CIEP). Available online at: https://www.clingendaelenergy.com/inc/upload/files/CIEP_paper_ 2017-02_web.pdf

O'Neill, E. G., and Maravelias, C. T. (2021). Towards integrated landscape design and biofuel supply chain optimization. Curr. Opin. Chem. Eng. 31:1006. doi: 10.1016/j.coche.2020.100666

Panoutsou, C., Germer, S., Karka, P., Papadokonstantakis, S., Kroyan, Y., Wojcieszyk, M., et al. (2021). Advanced biofuels to decarbonise european transport by 2030: markets, challenges, and policies that impact their successful market uptake. Energy Strategy Reviews. 34:100633.

Parker, N., Tittmann, P., Hart, Q., Nelson, R., Skog, K., Schmidt, A., et al. (2010). Development of a biorefinery optimized biofuel supply curve for the Western United States. Biomass Bioenergy 11, 1597-1607. doi: 10.1016/j.biombioe.2010.06.007

Paulauskiene, T., Bucas, M., and Laukinaite, A. (2019). Alternative fuels for marine applications: biomethanol-biodiesel-diesel blends. Fuel, 248, 161-167. doi: 10.1016/j.fuel.2019.03.082

Pérez-Fortes, M., Laínez-Aguirre, J. M., Arranz-Piera, P., Velo, E., and Puigjaner, L. (2012). Design of regional and sustainable bio-based networks for electricity generation using a multi-objective MILP approach. Energy 44, 79-95. doi: 10.1016/j.energy.2012.01.033

Phillips, S., Aden, A., Jechura, J., and Dayton, D. (2007). Thermochemical Ethanol via Indirect Gasification and Mixed Alcohol Synthesis of Lignocellulosic Biomass. Technical Report NREL/TP-510-41168. Available online at: https://www.nrel. gov/docs/fy07osti/41168.pdf

Pinho, A. D., de Almeida, M. B., Mendes, F. L., Casavechia, L. C., Talmadge, M. S., Kinchin, C. M., et al. (2017). Fast pyrolysis oil from pinewood chips coprocessing with vacuum gas oil in an FCC unit for second generation fuel production. Fuel 188, 462-473. doi: 10.1016/j.fuel.2016.10.032

Puigjaner, L., Pérez-Fortes, M., and Laínez-Aguirre, J. M. (2015). Towards a carbon-neutral energy sector: opportunities and challenges of coordinated 
bioenergy supply chains - A PSE approach. Energies 8, 5613-5660. doi: $10.3390 /$ en 8065613

Rentier, G., Lelieveldt, H., and Kramer, G. (2019). Varieties of coalfired power phase-out across Europe. Energy Policy 132, 620-632. doi: 10.1016/j.enpol.2019.05.042

Roni, M., Chowdhury, S., Mamun, S., Marufuzzaman, M., Lein, W., and Johnson, S. (2017). Biomass co-firing technology with policies, challenges, and opportunities: a global review. Renew. Sustain. Energy Rev. 78, 1089-1101. doi: 10.1016/j.rser.2017.05.023

Sadhukhan, J., Ng, K., and Martinez-Hernandez, E. (2014). Biorefineries and Chemical Processes: Design, Integration and Sustainability Analysis. Chichester: Wiley. doi: 10.1002/9781118698129

Sandén, B., and Pettersson, K. (2013). Systems Perspectives on Biorefineries. Chalmers University of Technology. Available online at: http://www.chalmers. se/en/areas-of-advance/energy/Documents/Systems\%20Perspectives\%20on/ Systems_Perspectives_on_Biorefineries_2014_v3.1b.pdf

Scarlat, N., Dallemand, J.-F., Skjelhaugen, O., Asplund, D., and Nesheim, L. (2011). An overview of the biomass resource potential of Norway for bioenergy use. Renew. Sustain. Energy Rev. 15, 3388-3398. doi: 10.1016/j.rser.2011. 04.028

Schröder, J., Müller-Langer, F., Aakko-Saksa, P., Winther, K., Baumgarten, W., and Lindgren, M. (2020). "Methanol as motor fuel - summary report," in Annex 56, A Report from the Advanced Motor Fuels Technology Collaboration Programme by IEA. Available online at: https://www.iea-amf.org/app/webroot/ files/file/Annex\%20Reports/AMF_Annex_56.pdf

Shah, Y. T. (2013). "Chapter 12: Biomass to liquid fuel via FischerTropsch and related syntheses," in Advanced Biofuels and Bioproducts (Norfolk, VA: Springer New York Heidelberg Dordrecht London), 185-208. doi: 10.1007/978-1-4614-3348-4_12

Sharma, K., Pedersen, T. H., Toor, S. S., Schuurman, Y., and Rosendahl, L. A. (2020). Detailed investigation of compatibility of hydrothermal liquefaction derived biocrude oil with fossil fuel for corefining to drop-in biofuels through structural and compositional analysis. ACS Sustain. Chem. Eng. 8, 8111-8123. doi: 10.1021 /acssuschemeng. 9 b06253

Sikarwar, V. S., Zhao, M., Fennell, P. S., Shah, N., and Anthony, E. J. (2017). Progress in biofuel production from gasification. Prog. Energy Combust. Sci. 61, 189-248. doi: 10.1016/j.pecs.2017.04.001

Sims, R. E. H., Mabee, W., Saddler, J. N., and Taylor, M. (2010). An overview of second generation biofuel technologies. Bioresour. Technol. 101, 1570-1580. doi: 10.1016/j.biortech.2009.11.046

Singh, A., Christensen, T., and Panoutsou, C. (2021). Policy review for biomass value chains in the European bioeconomy. Global Trans. 3, 13-42. doi: 10.1016/j.glt.2020.11.003

Stefanidis, S. D., Kalogiannis, K. G., and Lappas, A. A. (2018). Co-processing biooil in the refinery for drop-in biofuels via fluid catalytic cracking. WIREs Energy Environ. 7:e281. doi: 10.1002/wene.281

Swanson, R. M., Satrio, J. A., Brown, R. C., Platon, A., and Hsu, D. D. (2010). Techno-Economic Analysis of Biofuels Production Based on Gasification. Technical report, NREL/TP-6A20-46587. Available online at: https://www.nrel. gov/docs/fy11osti/46587.pdf

Thunman, H., Gustavsson, C., Larsson, A., Gunnarsson, I., and Tengberg, F. (2019). Economic assessment of advanced biofuel production via gasification using cost data from the GoBiGas plant. Energy Sci. Eng. 7, 217-229. doi: $10.1002 /$ ese 3.271

Thunman, H., Seemann, M., Berdugo Vilches, T., Maric, J., Pallares, D., Str?m, H., et al. (2018). Advanced biofuel production via gasification - lessons learned from 200 man-years of research activity with Chalmers' research gasifier and the GoBiGas demonstration plant. Energy Sci. Eng. 6, 6-34. doi: 10.1002/ ese 3.188
Tong, K., Gleeson, M. J., Rong, G., and You, F. (2013a). Optimal design ofadvanced 'drop-in' hydrocarbon biofuel supply chain integrating with existing petroleum refineries under uncertainty. Biomass Bioenergy 60, 108-120. doi: 10.1016/j.biombioe.2013.10.023

Tong, K., Gong, J., Yue, D., and You, F. (2013b). Stochastic programming approach to optimal design and operations of integrated hydrocarbon biofuel and petroleum supply chains. ACS Sustain. Chem. Eng. 2, 49-61. doi: $10.1021 / \mathrm{sc} 400267 \mathrm{t}$

Tunå, P., Hulteberg, C., Hansson, J., Åsblad, A., and Andersson, E. (2012). Synergies from combined pulp and paper and fuel production. Biomass Bioenergy 40, 174-180. doi: 10.1016/j.biombioe.2012.02.020

United Nations Climate Change (2016). The Paris Agreement. Available online at: https://unfccc.int/process-and-meetings/the-paris-agreement/theparis-agreement

van Dyk, S., Su, J., McMillan, J., and Saddler, J. (2019). Potential synergies of drop-in biofuel production with further co-processing at oil refineries. Biofuels Bioprod. Biorefin. 13, 760-775. doi: 10.1002/bbb.1974

Villanueva Perales, A. L., Reyes Valle, C., and Gomez-Barea, A. (2011). Technoeconomic assessment of ethanol production via thermochemical conversion of biomass by entrained flow gasification. Energy 36, 4097-4108. doi: $10.1016 /$ j.energy.2011.04.037

Werner, S. (2017). International review of district heating and cooling. Energy 137, 617-631. doi: 10.1016/j.energy.2017.04.045

Xing, T., Alvarez-Majmutov, A., Gieleciak, R., and Chen J. (2019). Co-hydroprocessing HTL biocrude from waste biomass with bitumen-derived vacuum gas oil. Energy Fuels 33, 11135-11144. doi: 10.1021/acs.energyfuels.9b02711

Xu, Y., Yang, K., Zhou, J., and Zhao, G. (2020). Coal-biomass co-firing power generation technology: current status, challenges, and policy implications. Sustainability 12:3692. doi: 10.3390/su12093692

Yang, Z., Kumar, A., and Huhnke, R. L. (2015). Review of recent developments to improve storage and transportation stability of bio-oil. Renew. Sustain. Energy Rev. 50, 859-870. doi: 10.1016/j.rser.2015.05.025

Yilmaz Balaman, S., and Selim, H. (2014). A fuzzy multiobjective linear programming model for design and management of anaerobic digestion based bioenergy supply chains. Energy 74, 928-940. doi: 10.1016/j.energy.2014.07.073

You, F., Tao, L., Graziano, D. J., and Snyder, S. W. (2012). Optimal design of sustainable cellulosic biofuel supply chains: multiobjective optimization coupled with life cycle assessment and input-output analysis. AIChE J. 58, 1157-1179. doi: 10.1002/aic. 12637

Yue, D., You, F., and Snyder, S. W. (2014). Biomass-to-bioenergy and biofuel supply chain optimization: overview, key issues and challenges. Comput. Chem. Eng. 66, 36-56. doi: 10.1016/j.compchemeng.2013.11.016

Zetterholm, J., Ahlstrom, J., and Bryngemark, E. (2020). Large-scale introduction of forest-based biorefineries: Actor perspectives and the impacts of a dynamic biomass market. Biomass Bioenergy. 142:105782. doi: $10.1016 /$ j.biombioe.2020.105782

Conflict of Interest: The authors declare that the research was conducted in the absence of any commercial or financial relationships that could be construed as a potential conflict of interest.

Copyright () 2021 Karka, Johnsson and Papadokonstantakis. This is an open-access article distributed under the terms of the Creative Commons Attribution License (CC $B Y)$. The use, distribution or reproduction in other forums is permitted, provided the original author(s) and the copyright owner(s) are credited and that the original publication in this journal is cited, in accordance with accepted academic practice. No use, distribution or reproduction is permitted which does not comply with these terms. 